\title{
ASPECTOS RELACIONADOS AO USO E APROPRIAÇÃO DE PRAÇAS EM ÁREAS CENTRAIS DE CIDADES: TRANSFORMAÇÕES E PERMANÊNCIAS ${ }^{1}$
}

\section{Aspects related to the use and ownership of areas in central square of cities: transformations and residence}

\author{
Guilhermina Castro SILVA² \\ Wilza Gomes Reis LOPES ${ }^{3}$ \\ João Batista LOPES ${ }^{4}$
}

\section{RESUMO}

A Praça Landri Sales, em Teresina-PI, após um projeto de revitalização, voltou a ser um local propício às atividades urbanas e utilizado pela população. Este trabalho teve como objetivo identificar as alterações comportamentais do uso da praça desde a sua construção até hoje e os benefícios e/ou problemas ambientais causados pelas atividades exercidas no local, seu equipamento mobiliário e identificar as atividades econômicas existente. Com a reforma realizada em 2006, a Praça Landri Sales recuperou a sua função original e foram restabelecidos seus equipamentos e sua cobertura vegetal. $\mathrm{O}$ órgão público, desde a sua reforma, não permitiu que ambulantes e camelôs permanecessem neste espaço. Esta praça apresenta lazer ativo e passivo, mas infelizmente apresenta, também, sinais de vandalismo e falta de manutenção do mobiliário e equipamentos urbanos, principalmente no que se refere à iluminação.

Palavras-chave: Praça; Lazer; Mobiliário urbano.

\begin{abstract}
The Landri Sales Square, in Teresina, Piauí, after a revitalization project, became a place conducive to urban activities and used by the population. This study aimed at identifying the behavioral change of use of the square since its construction to date and the benefits and / or environmental problems caused by activities performed on site, its furnishings and equipment to identify the existing economic activities. With the reform in 2006, the Landri Sales Square regained its original function and their equipment and vegetation were restored. The public agency, since its reform, has not allowed to open market people to stay there. This square shows active and passive recreation but unfortunately, it shows also signs of vandalism and lack of maintenance of urban furniture and equipment, especially with regard to lighting.
\end{abstract}

Keywords: Square; Leisure; Furniture.

1 Parte da dissertação de mestrado apresentada pela primeira autora ao Programa Regional de Pós-Graduação em Desenvolvimento e Meio Ambiente da Universidade Federal do Piauí (PRODEMA/UFPI/TROPEN).

2 Tecnóloga em Meio Ambiente, Mestranda do PRODEMA/UFPI (guilherminacastro@hotmail.com).

3 Arquiteta, Professora do Departamento de Construção Civil e Arquitetura e do Programas de Pós-Graduação em Desenvolvimento e Meio Ambiente, PRODEMA/UFPI (izalopes@uol.com.br).

4 Engenheiro Agrônomo, Professor do Departamento de Zootecnia e dos Programas de Pós-Graduação em Ciência Animal e do PRODEMA da UFPI (lopesjb@pesquisador.cnpq.br). 


\section{INTRODUÇÃO}

O crescimento da população nas cidades, a partir do século XVIII, favoreceu o aumento de áreas edificadas para a moradia, indústrias, comércios e serviços. $O$ planejamento urbano se tornou essencial na interação do homem com a natureza devido aos problemas causados pela urbanização acelerada, modificando o espaço natural para atender suas necessidades fisiológicas. Os espaços públicos como as avenidas, ruas, calçadões, praças, parques, orla marítima têm a função de melhorar a qualidade ambiental proporcionando uma contribuição no fortalecimento da identidade local com a delimitação das áreas urbanizáveis.

Macedo (1995, p. 16) conceitua espaços livres como todos aqueles não contidos dentro das edificações, como "as ruas, praças, largos, pátios, quintais, parques, jardins, terrenos baldios, corredores externos, vilas, vielas", os quais são reconhecidos na malha urbana pelos relevantes aspectos de funcionalidade.

O espaço público é o local onde há interação e socialização das pessoas. Para Sirkis (2003) tal espaço é primordial no tecido urbano pela sua mistura de usos. Alex (2008) define "público" como um espaço aberto e acessível a todas às pessoas, sem exceção. Na visão de Vargas (2001, p. 98), o espaço público é tido como um "lugar onde uma pessoa pode estar sozinha sem dar a impressão de estar solitária". No espaço urbano há os espaços livres que estão situados em áreas sem edificações, podendo ser públicos ou privados, ou seja, o acesso é delimitado por grupo ou pessoa.

Para Landim (2004, p. 27) o espaço livre é um "elemento de aglutinação entre os diversos tipos de espaços edificados" que permite a apreensão, compreensão e o uso da forma urbana, cuja função básica seria possibilitar a circulação na cidade. Sá Carneiro e Mesquita (2000) relacionam outras funções como: equilíbrio ambiental (reservas ecológicas, jardins botânicos, parques nacionais, cemitérios, campi universitário), recreação (praças, parques, jardins, largos, pátios) e circulação (ruas, viadutos, estacionamentos). Loboda e De Angelis (2005) relatam que foi na Grécia que os espaços livres, pela primeira vez, assumiram a função pública, sendo considerados locais de passeio, conversa e lazer.

Dentre estes espaços públicos e abertos, destacam-se as praças, que segundo Spirn (1995, p. 89), "são lugares para ver e ser visto, para comprar e fazer negócios, para passear e fazer política". A praça nasceu da necessidade de um local acessível para a realização de funções como atividade de troca, tomada de decisões coletivas, ponto de encontro e festividades (BARTALINI, 2005).

A origem da praça está relacionada às ágoras das cidades gregas e romanas, onde "todos os cidadãos podiam discursar e manifestar suas idéias e respeito de qualquer problema" (GRAEFF, 1986, p. 130).

De uma maneira geral, as praças deixaram de ter a função primordial de lazer coletivo devido ao surgimento de novos lugares de encontro e reunião, como o shopping center, que funciona como grande concorrente da praça pública na cidade moderna, uma vez que oferece segurança, por ser um em espaço fechado, além de contar com estruturas de lazer e de sociabilidade. São espaços onde se concentram, também, vários serviços, como: cinema, lan house, lojas, shows, praça de alimentação, entre outros atraindo a população. Além disso, o acesso à televisão a cabo, pay-per-view, a internet, entre outros são inovações tecnológicas de lazer dentro de casa, que possibilitam conhecer novos ambientes, fazer amigos, realizar atividades lúdicas, como os jogos virtuais e até paquerar e namorar, desempenhando o papel típico das praças, em tempos passados.

Outro fator de abandono destes espaços diz respeito aos novos tipos de apropriação que com o tempo resultaram na perda do referencial histórico e cultural, acarretando uma desfiguração da paisagem urbana.

A mudança de uso e o afastamento da população dos espaços públicos aconteceram de forma mais significativa nas praças centrais da maioria das cidades, pois nestas áreas, acompanhando as transformações ocorridas na sociedade, a atividade comercial suplantou a residencial, modificando a relação da praça com seu entorno.

Planejada e construída, em 1852, com a finalidade de ser a capital do Estado do Piauí, Teresina já possuía em seu plano original várias áreas destinadas para construção de praças, contando hoje, em seu centro histórico com o total de sete praças: Praça Marechal Deodoro da Fonseca, Praça Rio Branco, Praça João Luis Ferreira, Praça Landri Sales, Praça Pedro II, Praça da Liberdade e Praça Saraiva, que hoje fazem parte do patrimônio cultural da cidade.

Este trabalho teve como objetivo estudar a evolução dos usos ao longo dos anos e as funções atuais, diagnosticar a situação geral, estado de conservação e infraestrutura existente e identificar como ocorre a apropriação pela população de praças em áreas centrais de cidades, tendo como enfoque a Praça Landri Sales, em Teresina. 
SILVA, G. C. et al. Aspectos relacionados ao uso e apropriação...

\section{PROCEDIMENTOS METODOLÓGICOS}

Para realização da pesquisa, foi selecionada a Praça Landri Sales que, embora apresente em seu entorno a predominância de atividades de comércio e de serviços, ainda são encontradas edificações residenciais nas proximidades e o Colégio Estadual Zacarias de Góis, conhecido como Liceu Piauiense. Dessa forma, os frequentadores utilizam o espaço para o desenvolvimento de atividades de maior permanência, como conversar, esperar o início das aulas, namorar e ainda pedalar, jogar, andar de patins e de skate. Além disso, este espaço passou por reformas, efetuadas pela Prefeitura Municipal de Teresina, com o objetivo de resgatar o interesse dos usuários pela apropriação de praças centrais, como espaço propício às atividades urbanas.

Foi realizado levantamento da memória do projeto e da construção, resgatando as mudanças ocorridas, por meio de documentos originais, fotografias, artigos em jornais, que descrevessem o período de construção das praças e a utilização destes espaços pela população.

A observação das estruturas funcionais e físicas teve a finalidade de identificar os diferentes tipos de usuários, as atividades desenvolvidas por eles e os horários mais utilizados. Para isso, as observações foram feitas a partir das $7 \mathrm{~h} 30 \mathrm{~min}$ até as $18 \mathrm{~h} 30 \mathrm{~min}$, em dias da semana e finais de semana típicos. O mapeamento comportamental foi focado nas pessoas que utilizavam o espaço da praça, nos seus percursos e no modo de utilização do espaço durante o tempo que permaneciam na praça em estudo (PINHEIRO et al., 2008). Para isso, foi feita uma representação gráfica da ocupação humana na praça relacionada com o espaço físico. A utilização de uma planta baixa da praça proporcionou uma melhor identificação dos espaços preferidos, atividades desenvolvidas e caminhos percorridos.

Também foi realizado o diagnóstico da situação geral da praça, a partir de avaliação qualitativa direta, com a identificação e descrição dos equipamentos e mobiliários existentes, como os bancos, pontos de iluminação, lixeiras, esculturas, monumentos, pisos, canteiros, segundo o método utilizado por De Angelis et al. (2004), que atribui valores que variam de 0,0 (zero) a 4,0 (quatro), na seguinte escala: 0 a 0,4 (péssimo); 0,5 a 1,4 (ruim); 1,5 a 2,4 (regular); 2,5 a 3,4 (bom); 3,5 a 4,0 (ótimo). A partir dos índices encontrados, foi avaliado se o ambiente atende aos requisitos de conforto do usuário e aos aspectos ligados à conservação do lugar. Os resultados foram tabulados em planilhas específicas, analisados e descritos de forma detalhada, em consonância com o objeto de estudo.

\section{A CIDADE DE TERESINA}

Teresina, capital do Piauí, estado da região Nordeste do Brasil, está situada à margem direita do rio Parnaíba, sendo banhada também pelo rio Poti, apresentando a posição geográfica de $5^{\circ} 5^{\prime} 12$ de latitude Sul e longitude Oeste de 42 48'42. De acordo com o IBGE (2007) a população de Teresina é de 779.939 habitantes. Devido à proximidade com a linha do Equador, os raios solares atingem à cidade com o ângulo muito próximo a $90^{\circ}$, permitindo que a cidade receba intensa radiação e apresente temperaturas elevadas na maior parte do ano (CASTELO BRANCO, 2003).

O plano da cidade de Teresina foi traçado e estruturado a partir de um rígido formato geométrico que lembrava um tabuleiro de xadrez, com suas ruas alinhadas, quarteirões pequenos e um grande largo circundado por prédios administrativos e religiosos. Suas ruas paralelas partiam do rio Parnaíba, a Oeste, em direção ao rio Poti e sua ocupação iniciaram nos sete primeiros quarteirões para o sul e três para o norte, organizado a partir da igreja do Amparo (DIAS, 2006).

Para Gomes e Soares (2003, p. 20), no Brasil, no século XIX, "existiam cidades que se destacavam pela quantidade expressiva do verde no seu interior, como é o caso de Teresina/PI, com densa arborização".

Geralmente, o cuidado com as praças de Teresina tem sido uma preocupação constante dos administradores municipais, ao longo dos anos. O prefeito Lindolfo do Rego Monteiro, em seu relatório de atividades, referente ao exercício de 1941, destaca a importância dessas áreas para a cidade de Teresina, devido às condições do clima local, e ainda aponta a necessidade da abertura de novas praças e da conservação e melhoria das existentes (MONTEIRO, 1943).

As praças do centro de Teresina têm uma representação significativa em relação à quantidade de cobertura vegetal, criando grandes áreas sombreadas. No entanto, esses espaços estão sofrendo descaracterização e destruição, tornando-se áreas marginalizadas devido à falta de infraestrutura, segurança e educação ambiental. Isso se deve à má conservação, invasão de novos usos, falta de conscientização quanto ao valor histórico e cultural, depredação por vandalismo dos marcos e mobiliário, entre outros. Tudo isso acaba causando o abandono e a ocupação indevida, deixando os usuários de utilizar seus serviços devido à falta de uma política de melhoria urbana. 


\section{INÍCIO E EVOLUÇÃO DA PRAÇA LANDRI SALES}

A Praça Landri Sales, conhecida também como Praça do Liceu, teve sua origem com a delimitação de seu espaço físico pelo fundador de Teresina, ConseIheiro Saraiva, na planta datada de 1855. Esse espaço abrangia dois quarteirões contíguos, com uma parte elevada, o Alto da Pitombeira, e outra parte baixa, que mais tarde seria conhecida como Baixa da Égua. No
Alto da Pitombeira foi construído o Colégio Estadual Zacarias de Góis, conhecido como Liceu Piauiense (Figura 1), inaugurado em 1936, tendo a parte baixa do largo do poço sido reservada para a praça. Garcia (2000, p. 37) comenta que a praça "foi batizada com o nome de Landri Sales, mas não pegou. O povo preferiu denominá-la vulgarmente de Praça do Liceu".

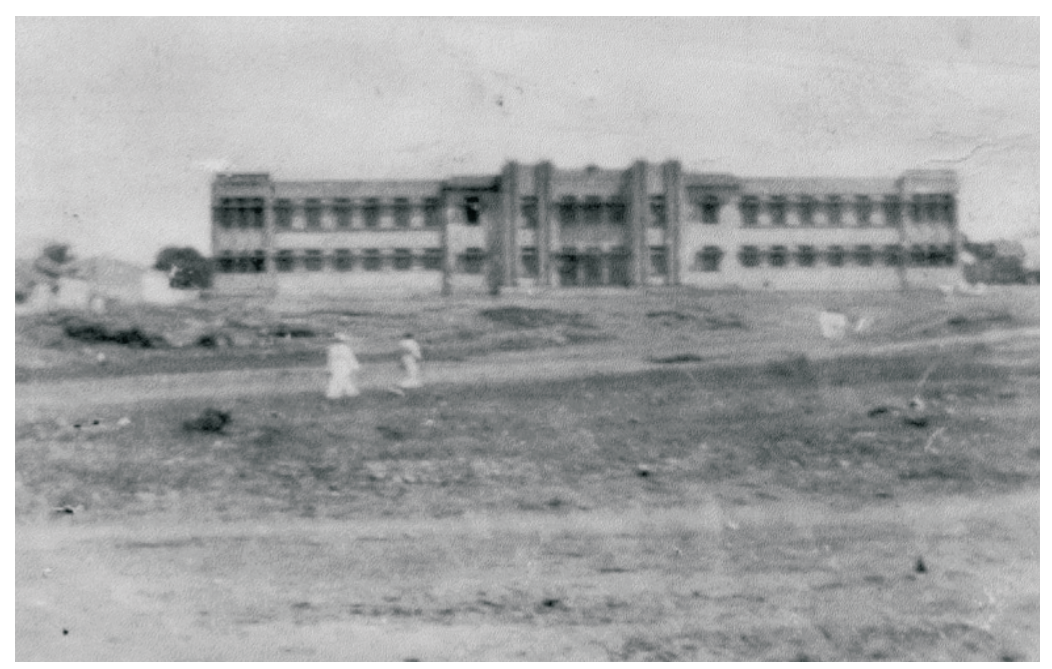

FIGURA 1 - ESPAÇO LIVRE DESTINADO À CONSTRUÇÃO DA PRAÇA LANDRI SALES EM FRENTE AO LICEU PIAUIENSE, INAUGURADO EM 1936

FONTE: Acervo Colégio Estadual Zacarias de Góis.

O terreno era acidentado e no inverno se transformava em ninho de cobras e mosquitos, além de formar poças de lama. No verão, servia de campo de futebol e hospedagem dos circos que visitavam Teresina. A sua transformação em praça foi uma promessa de Agenor Barbosa de Almeida, candidato a prefeito. Durante o seu mandato (1955-1959) ele não poupou esforços para cumprir sua promessa, empregando pessoas e usando mão de obra dos presidiários, que utilizavam dinamite para explodir as pedras. Com essas explosões eram expelidos fragmentos que destruíam vidraças das casas próximas e, também, interrompiam as aulas do colégio (GARCIA, 2000).

Em 1955, foi iniciada a construção da praça, em uma área de $8.271,23 \mathrm{~m}^{2}$. A sua construção causou muitos protestos por parte da imprensa e dos adversários políticos do prefeito Agenor Barbosa, sendo destacados nos jornais da época, os incidentes acontecidos durante a construção, como o divulgado no jornal $O$ Dia, em 1955.

\begin{abstract}
A cidade quinta-feira foi abalada com a notícia de que o Sr. José Basílio da Silva teria sido vítima de uma pancada no crâneo, motivada por um estilhaço de pedra, vindo das explosões de dinamites aplicadas na pedreira da Praça Lanri Sales, onde estão sendo feitos serviços de pavimentação da referida praça. [...] O Sr. Prefeito da Capital não pode desconhecer que daquela forma tal serviço é inadmissível nas grandes artérias das cidades. Deveria ter autorizado outros processos para a quebra da pedreira, mas acima do interesse da coletividade está o interêsse pessoal do Prefeito de acelerar os serviços daquele logradouro público onde está encravado o seu palacete residencial (PERIGOSA..., 1955, p. 4).
\end{abstract}

A construção da praça não despertou apenas críticas, tendo sido bem recebida, como pode ser comprovado, em matéria de jornal local, no período final da construção, que afirmava: "O prefeito Agenor Almeida está concluindo os trabalhos de construção da Praça Landri Sales, uma verdadeira maravilha, e por cujo trabalho aplaudimos, pelo esforço que representa para 
uma melhor urbanização da cidade, o edil" (PRAÇAS, 1957, p. 2).

Segundo Martins (1959, p. 41), a praça apresentava, em 1957, um aspecto magnífico, e a descreve, afirmando que:

Toda ela foi planejada em elegante estilo tropical, recortada de aléias de palmeiras de nossa terra, transplantadas adultas; pavimentada oriundas de diversas regiões do Estado, contendo um abrigo de feitio moderno, onde funcionam café, bar e instalações sanitárias públicas. Tem iluminação fluorescente que muito embeleza seus vários planos, em que se alternam balaustres, passeios, lagos, pontes e grutas artisticamente dispostos.

O projeto, de autoria e execução de Raimundo Nonato de Portela de Melo, foi concebido, segundo Marques (2005, p. 12), "em estilo eclético (lago, fonte

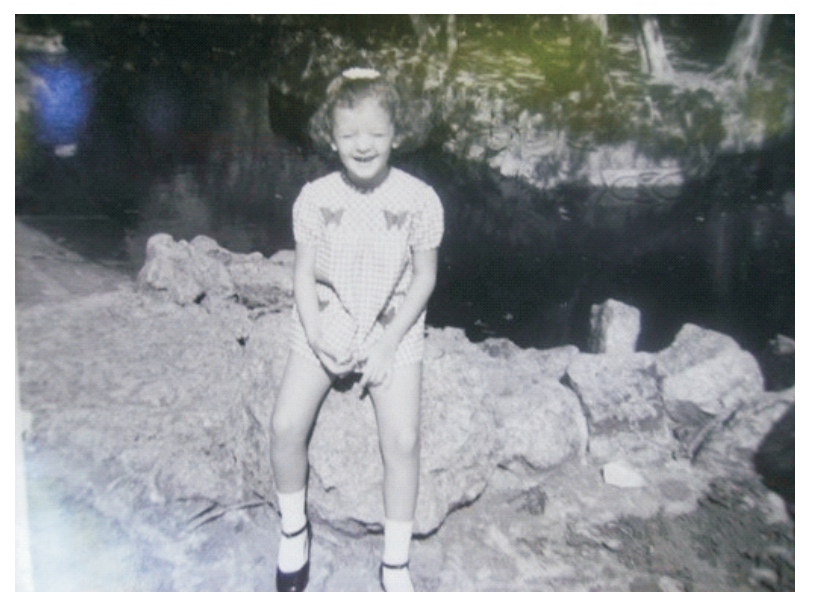

FIGURA 2 - CRIANÇA NA PRAÇA LANDRI SALES, VENDO-SE O LAGO COM PEDRA

FONTE: Acervo da Família Reverdosa.

Com a expansão da cidade, na década de 1980, surgiram grandes conjuntos habitacionais, em locais afastados do centro, enquanto que no início dos anos 1990, teve início o processo de verticalização da cidade, concentrando-se na zona Leste, devido à localização e infraestrutura com edifícios de alto padrão. Isto favoreceu a mudança da população que residia no centro da cidade para estes bairros, fazendo com que as áreas centrais adquirissem o caráter comercial. Neste sentido, Lamas (2004, p. 54) afirma que, com o passar dos com elementos decorativos, arco em pedra, gruta e balaustradas neocoloniais em semicírculos) com alguns elementos do estilo moderno (canteiros geométricos desestruturados distribuídos de forma orgânica)".

Almeida (2005, p. 49) comenta que foi exigido que no projeto fosse utilizado: "[...] árvores nativas e que aproveitasse o grotão de pedras ali existentes. Foi a primeira praça na capital piauiense a receber energia elétrica com emprego de lâmpadas fluorescentes e piso calçado com lajes advindas de Piracuruca"5.

Para Marques (2005), a praça atraía babás e famílias com as crianças casais de namorados, e idosos por possuir uma atmosfera acolhedora (Figuras 2 e 3). Com o passar dos anos a praça sofreu fortes descaracterizações em seu espaço. Ainda segundo a referida autora, no final da década de 1970, o lago, a fonte e a gruta foram extintos por se tornarem foco de contaminação e refúgio para marginais.

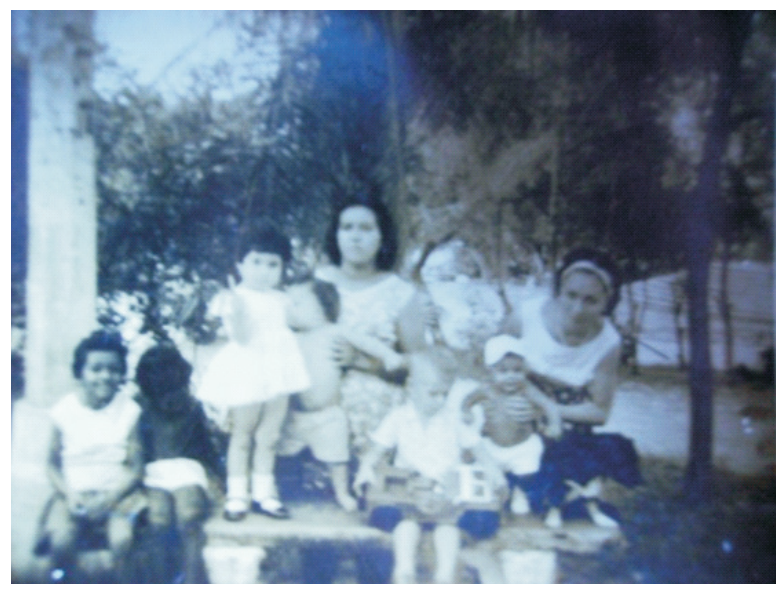

FIGURA 3 - FAMÍLIAS COM CRIANÇAS POSANDO PARA FOTO NA PRAÇA LANDRI SALES

FONTE: Acervo da Família Reverdosa.

anos, os centros urbanos "passaram de lugar de defesa e poder a lugares de comércio, serviços e trocas culturais", havendo uma sobreposição de funções, devido à complexidade e dinâmica das cidades.

A partir da década de 1990, a Praça Landri Sales começou a ser utilizada para a realização de feira dos livros usados, com autorização da prefeitura até 2005. No início, os livros eram expostos de maneira improvisada e em equipamentos removíveis (Figura 4), mas depois foram colocados boxes metálicos, dificultando

5 Piracuruca refere-se ao município do estado do Piauí, localizado a 196 km de Teresina, que entre suas atividades econômicas está o extrativismo de pedras, muito usadas na arquitetura e engenharia. 
a circulação dos usuários, como também, danificando o piso, o mobiliário, a vegetação e desfigurando a paisagem da praça e do seu entorno (Figura 5).

À noite, a praça se tornava um local propício à marginalidade, devido à presença dos boxes que se transformavam em "labirintos". Além disso, a feira dos livros, por ter um grande fluxo de pessoas, atraía outros tipos de comércio informal, como vendedores de lanches, vales, refrigerantes, água, entre outros, que, ao final do dia, deixaram visível os vestígios de sua passagem, ao deixarem a praça suja e danificada, não primando pela limpeza e conservação do espaço público.

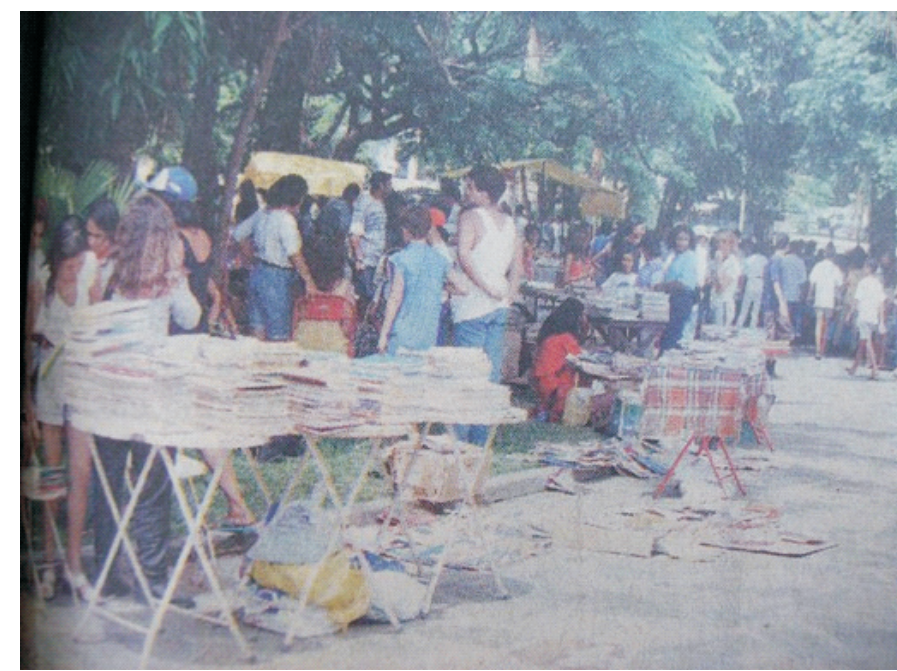

FIGURA 4 - FEIRA DO LIVRO USADO NA PRAÇA LANDRI SALES, EM 1997

FONTE: Colégio... (1997, p. 11).

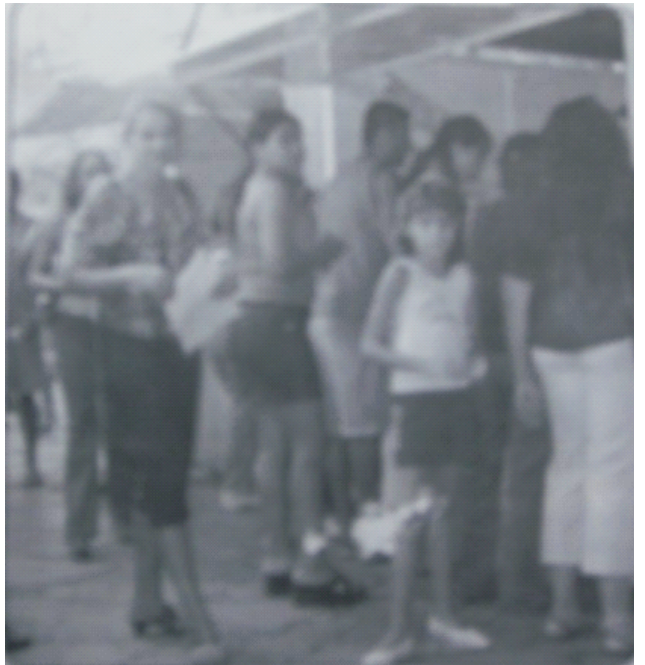

FIGURA 5 - FEIRA DO LIVRO USADO NA PRAÇA LANDRI SALES, EM 2005

FONTE: Maranhão... (2005, p. 5).
Em 2006, a praça passou por uma reforma, que manteve o traçado da época de 1970, recebendo a aplicação de um novo piso, em concreto e pedra portuguesa (Figura 6), material mais propício para locomoção. Além disso, foram realizados trabalhos de replantio de novas espécies vegetais, jardinagem e poda de árvores, e também, a recuperação de todo o sistema de iluminação, tendo sido colocados novos bancos de concreto.

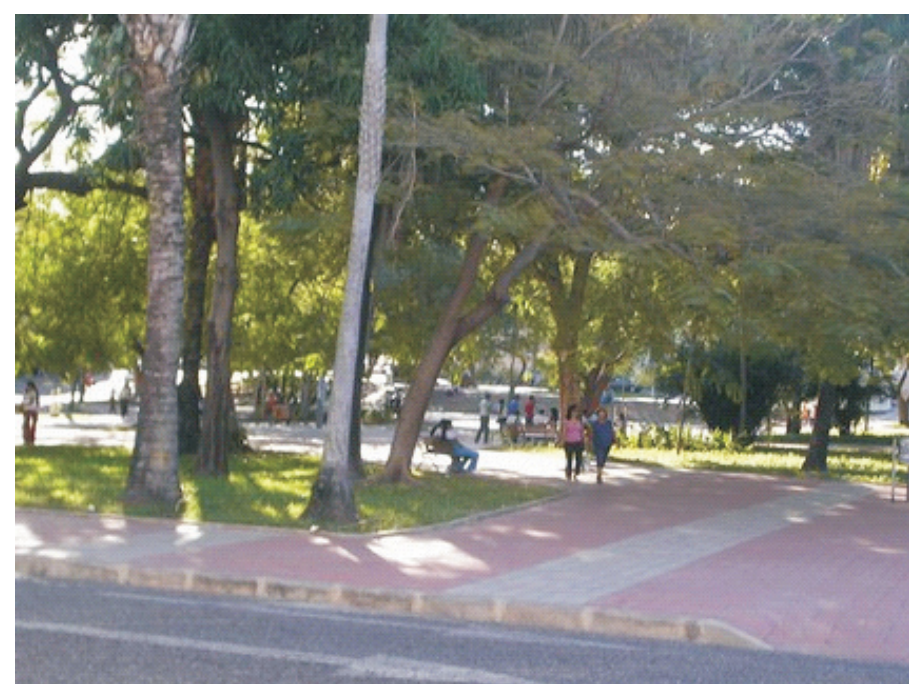

FIGURA 6 - PISO EM BLOCOS DE CONCRETO E PEDRA PORTUGUESA NA PRAÇA LANDRI SALES

FONTE: Foto Guilhermina Castro, 2007. 
A reforma teve como objetivo principal resgatar a identificação dos usuários com a praça, tornando o espaço, mais uma vez, um local propício às atividades urbanas e, devidamente, apropriado pela população.
A praça passou a ser novamente, utilizada, admirada e contemplada pelos teresinenses. A população voltou a permanecer na praça, devido à sua estética, vegetação, conforto, história e memória.

\section{A PRAÇA E SEUS EQUIPAMENTOS: DA CRIAÇÃO AOS DIAS ATUAIS}

O mobiliário urbano em espaços públicos passou a ser introduzido em resposta às necessidades sociais urbanas e técnicas, com isso, as praças passaram a ter um destaque na socialização urbana, devido ao seu mobiliário e equipamentos urbanos.

Para Montenegro (2005, p. 35), "Em um primeiro momento, as praças passam a ser sinônimo de lazer e descanso onde é possível encontrar chafarizes, estátuas e marcos que caracterizam alguns locais e também a cidade, sendo posteriormente instalados outros elementos como bancos, iluminação e coretos".

O terreno onde foi construída a praça possuía

grandes blocos de pedras, que foram aproveitadas para a construção da escadaria. Com a construção concluída, este espaço tornou-se movimentado e de acordo com Garcia (2000, p. 37) "as rochas, abrigo dos estudantes com as curicas ${ }^{6}$, foram aproveitadas e transformadas em grutas e lagos artificiais. O piso de lajes, [...], combinava com os canteiros de plantas tropicais". Com a reforma de 2006, a praça recebeu a instalação do piso em concreto e pedra portuguesa, material mais propício para locomoção, na escadaria o piso é em pedra de Piracuruca (Figura 7). A escadaria apresenta atualmente danificação nos degraus.

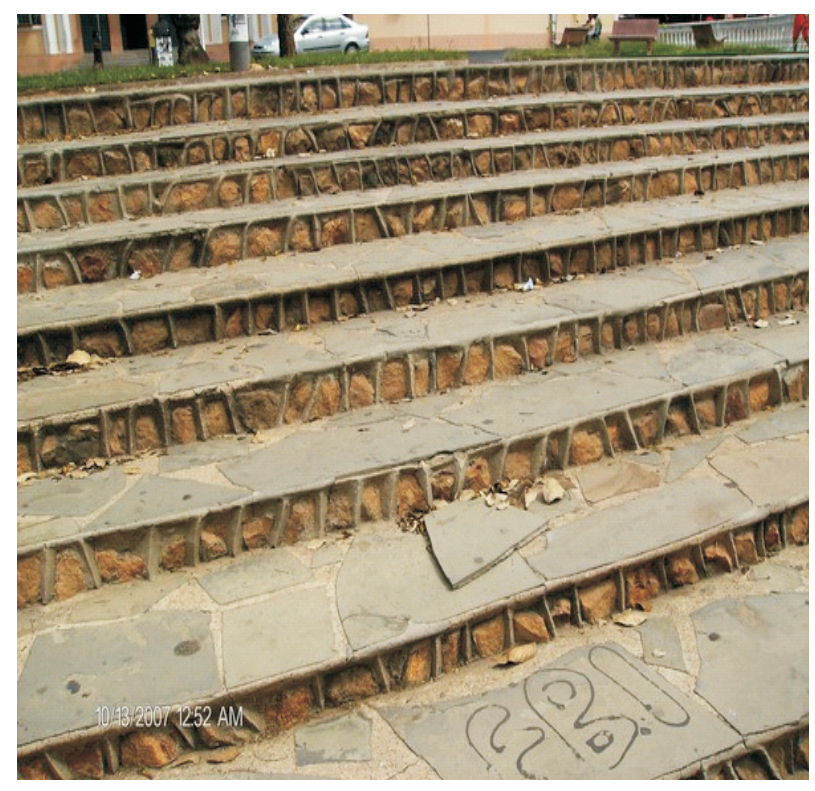

FIGURA 7 - ESCADARIA EM PEDRA DE PIRACURUCA DA PRAÇA LANDRI SALES

FONTE: Foto Guilhermina Castro (2008).

6 De acordo com Garcia (2000), era uma expressão usada na época em relação às empregadas domésticas. 
A partir de 2006, a praça foi adaptada para dar acesso aos portadores de deficiência, com rampas e a introdução de um orelhão adaptado para cadeirantes ou portadores de acondroplasia (nanismo). Infelizmente, estas medidas não contemplam todos os portadores com deficiência, como, por exemplo, os cegos. A falta de acessibilidade e de integração dos mobiliários e equipamentos urbanos em espaços públicos apresenta uma barreira com os usuários, podendo provocar acidentes ou mesmo desconforto aos idosos e portadores de deficiência.

A praça apresenta 15 bancos distribuídos em dois modelos, sendo que seis são de concreto com encosto na cor vermelha (Figura 8), que estão localizados na

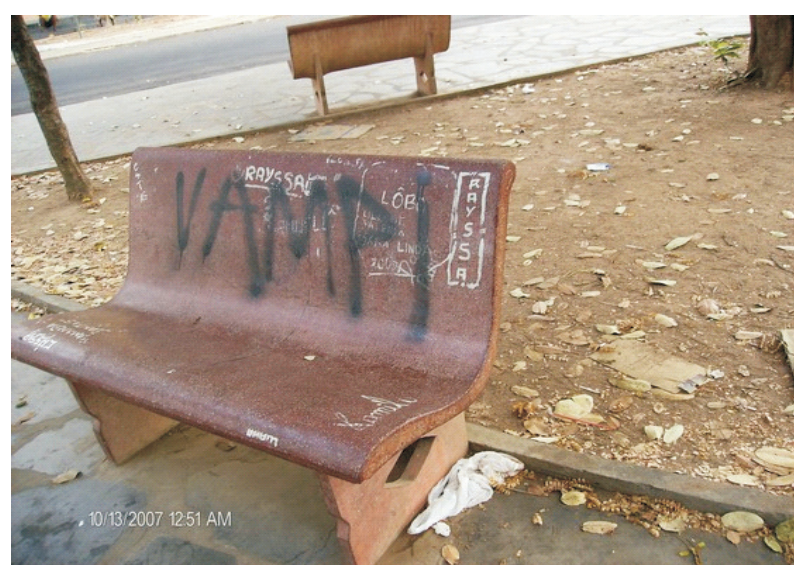

FIGURA 8 - BANCO DE CONCRETO COM ENCOSTO EM CIMA DA ESCADARIA NA PRAÇA LANDRI SALES

FONTE: Foto Guilhermina Castro (2008).

Foram introduzidos novos bancos com assento e encosto de madeira com estrutura de ferro e sua distribuição foi na parte interna da praça, sempre próximas às árvores, visando proporcionar conforto aos usuários parte superior e nove em concreto sem encosto e com pés adornados, cujos desenhos são originários do início da praça (Figura 9), situados na parte mais baixa da praça. Cavalcanti $(1958$, p.7) comenta que "o serviço de bancos está simetricamente disposto, atendendo a todos os gostos dos visitantes".

Antes da reforma, em 2006, os bancos apresentavam sinais de vandalismo (quebrados e riscados). $\mathrm{Na}$ reforma, foram feitas réplicas dos seis bancos que ficavam em cima da escadaria, já que não poderiam ser recuperados e os bancos da parte baixa foram recuperados e distribuídos no entorno da praça. Hoje, os bancos da parte superior já apresentam sinais de vandalismo, com várias pichações.

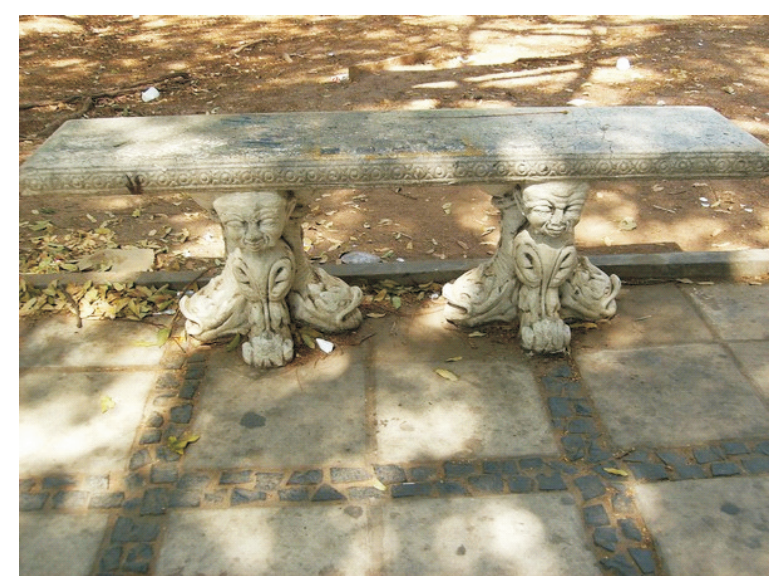

FIGURA 9 - BANCO DE CONCRETO COM PÉS ADORNADOS E SEM ENCOSTO NA PRAÇA LANDRI SALES

FONTE: Foto Guilhermina Castro (2008).

que aproveitam a sombra das árvores e apreciam a sua beleza. Estes bancos também apresentam sinais de vandalismo, encontrando-se riscados e quebrados (Figura 10). 


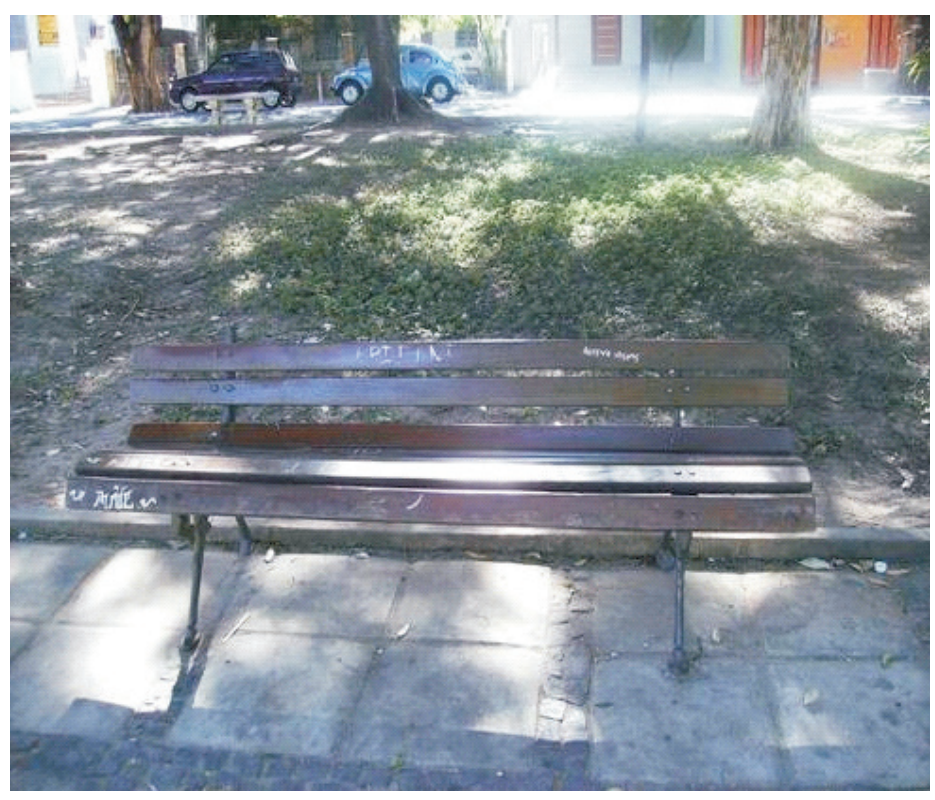

FIGURA 10 - BANCO DE ESTRUTURA DE FERRO E MADEIRA, COM ENCOSTO, NA PRAÇA LANDRI SALES

FONTE: Foto Guilhermina Castro (2008).

Com a reforma, foram criados espaços de encontro e convivência, com a inclusão de mesas de jogos e bancos individuais, em concreto, situados perto da escadaria (Figura 11) e em área mais central da praça.

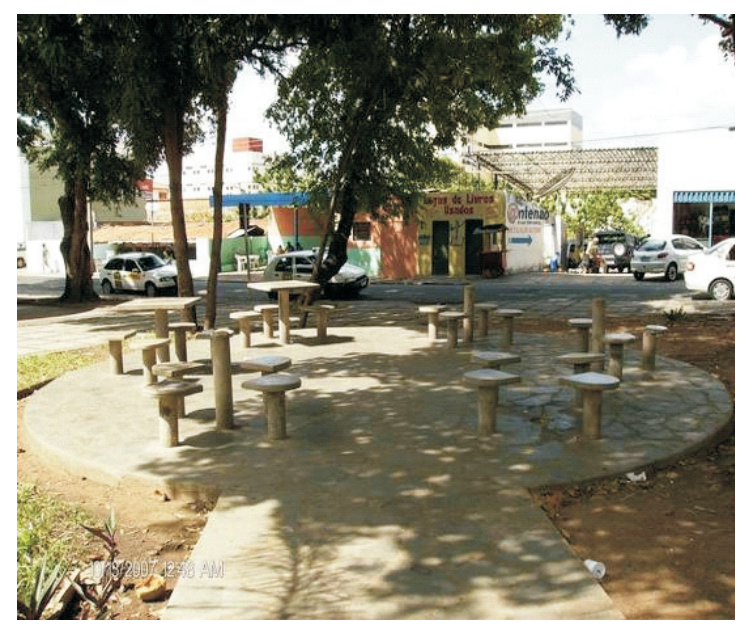

FIGURA 11 - MESAS DE JOGOS PRÓXIMOS À ESCADARIA NA PRAÇA LANDRI SALES

FONTE: Foto Guilhermina Castro (2008).
Atualmente, já existem mesas e bancos quebrados (Figura 12), mas que mesmo assim ainda são locais utilizados pelos usuários.

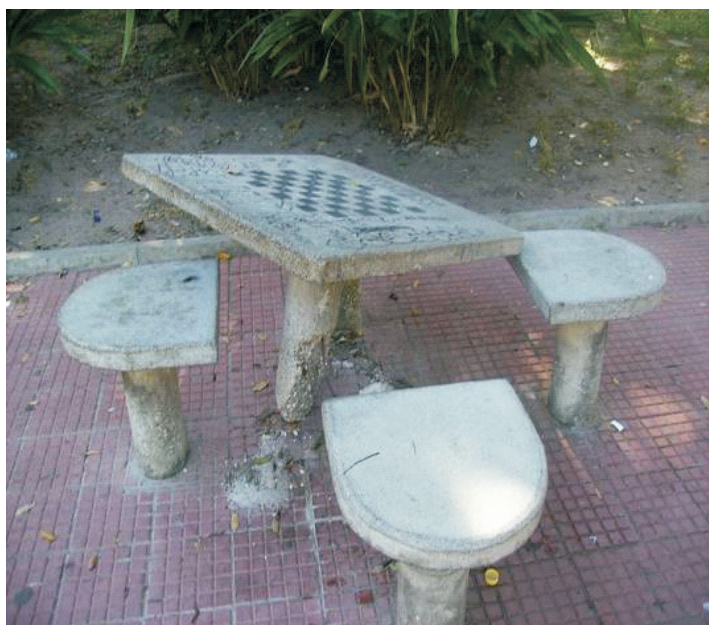

FIGURA 12 - MESA DE JOGO QUEBRADA NA PRAÇA LANDRI SALES

FONTE: Foto Guilhermina Castro (2008). 
A praça possui uma boa distribuição de lixeiras (Figura 13), sendo que duas já estão quebradas, restando

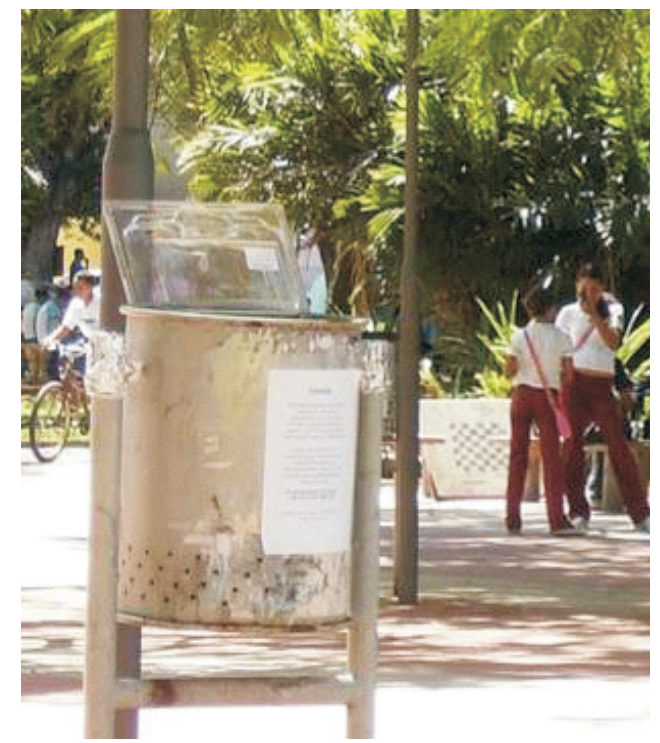

FIGURA 13 - LIXEIRA DE METAL COM SUPORTE NA PRAÇA LANDRI SALES

FONTE: Foto Guilhermina Castro (2008).

Logo após a inauguração, em 1958, a iluminação da praça chamava a atenção dos habitantes, sendo um atrativo a mais do local, como observado, no relato de Cavalcanti (1958, p. 7), ao descrever, "passei à noite pela Praça Landri Sales e fiquei maravilhado com aquela imponência de iluminação, por meio das célebres lâmpadas fluorescentes". E continua a descrição, afirmando que os visitantes não podem "praticar nenhum ato indecente ou contra a moral pública naquele logradouro apenas o suporte (Figura 14). A manutenção da praça é diária, proporcionando a adequada limpeza do local.

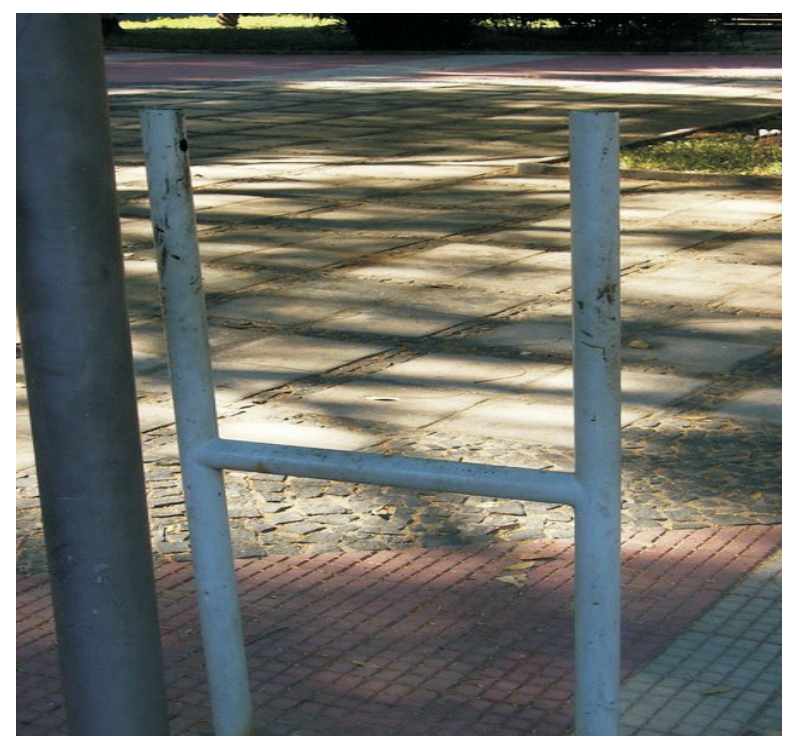

FIGURA 14 - LIXEIRA QUEBRADA, SINAL DE VANDALISMO NA PRAÇA LANDRI SALES

FONTE: Foto Guilhermina Castro (2008).

municipal devido à farta e eficiente iluminação elétrica" (CAVALCANTI, 1958, p. 7).

Na década de 1970, a iluminação original da praça foi substituída por dois postes de $8 \mathrm{~m}$ de altura com quatro pétalas cada (MARQUES, 2005). Hoje, além destes, a praça possui nove postes com $2 \mathrm{~m}$ de altura, introduzidos na reforma de 2006, para proporcionar áreas bem iluminadas aos frequentadores (Figura 15).

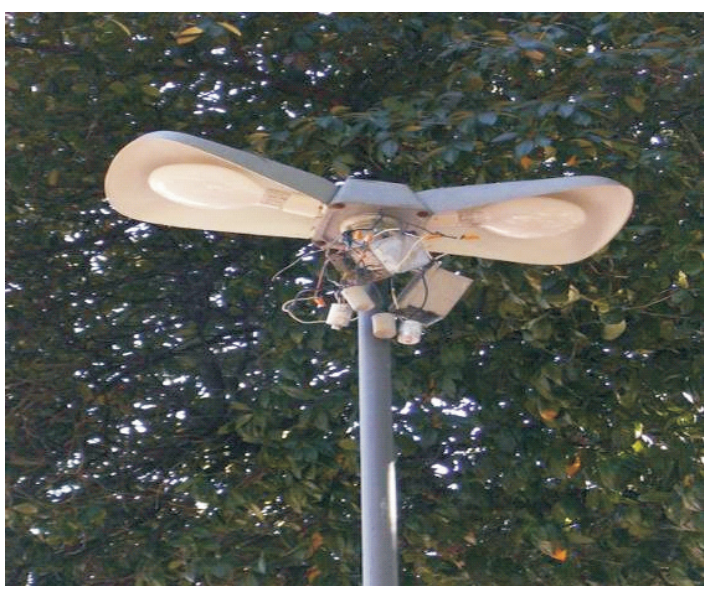

FIGURA 15 - POSTES COM 4 PÉTALAS E 2 PÉTALAS NA PRAÇA LANDRI SALES

FONTE: Foto Guilhermina Castro (2008). 
SILVA, G. C. et al. Aspectos relacionados ao uso e apropriação...

Na tabela 1 estão apresentados o levantamento, a descrição e a avaliação dos equipamentos existentes, no espaço estudado, com relação aos tipos, à quantidade, e ao estado de conservação.

TABELA 1 - LEVANTAMENTO DOS EQUIPAMENTOS EXISTENTES NA DA PRAÇA LANDRI SALES

\begin{tabular}{|c|c|c|}
\hline $\begin{array}{l}\text { Equipamentos e } \\
\text { Mobiliário Urbano }\end{array}$ & Quantidade e Descrição & Nota \\
\hline Placas de sinalização & $\begin{array}{l}02 \text { com nomenclatura de ruas; } \\
04 \text { com sinalização de trânsito (sinalização de } \\
\text { advertência, indicativa e de regulamentação) }\end{array}$ & 3,5 \\
\hline $\begin{array}{l}\text { Quiosque de alimentação } \\
\text { e/ou similar }\end{array}$ & $\begin{array}{l}\text { Local que, atualmente, funciona como ponto de } \\
\text { alimentação. Construção de alvenaria e cobertura em } \\
\text { laje de concreto, possuindo instalações sanitárias. }\end{array}$ & 3,5 \\
\hline Escadaria & Revestida com pedra de Piracuruca & 3,0 \\
\hline Telefone público & $\begin{array}{l}03 \text { orelhões tipo padrão (orelhinha), de fibra } \\
\text { de vidro (fiberglass), sendo que } 2 \text { estão } \\
\text { adaptados para pessoas especiais. }\end{array}$ & 3,0 \\
\hline Lixeiras & $\begin{array}{l}13 \text { de material metálico (folha de flandre) com suporte } \\
\text { também metálico. Duas delas estão quebradas, existindo } \\
\text { apenas o suporte. Estão distribuídas regularmente no local. }\end{array}$ & 2,5 \\
\hline Bancos de concreto com encosto & 09 bancos com modelo de encosto de concreto vermelho & 2,5 \\
\hline Bancos de concreto sem encosto & 06 sem encosto em concreto com apoios adornados; & 2,5 \\
\hline Iluminação baixa & $\begin{array}{l}09 \text { postes com } 2 \text { m de altura para propiciar iluminação } \\
\text { adequada aos transeuntes, situados no entorno da praça. }\end{array}$ & 2,5 \\
\hline Iluminação alta & 2 postes de ferro com $8 \mathrm{~m}$ com quatro pétalas cada & 2,0 \\
\hline Bancos de madeira com ferro & $\begin{array}{l}14 \text { bancos de madeira com pé de ferro, } \\
\text { com assento e encosto de madeira; }\end{array}$ & 2,0 \\
\hline Obra de arte & $\begin{array}{l}\text { Busto do Interventor Landri Sales, que é de } \\
\text { cimento com pedestal em concreto. }\end{array}$ & 2,0 \\
\hline Mesas de jogo de tabuleiro & $\begin{array}{l}04 \text { mesas de jogo de concreto e } 04 \text { com bancos; } \\
04 \text { mesas de jogo de concreto e } 03 \text { com bancos. }\end{array}$ & 2,0 \\
\hline
\end{tabular}

Em relação aos seus equipamentos, considera-se que a praça estudada apresenta um nível médio de conservação. Alguns equipamentos obtiveram o conceito ótimo, a partir de critérios de conservação de utilização e de quantidade no espaço. Dessa forma, as placas de sinalização, que estão bem distribuídas na praça e a construção, onde funciona uma lanchonete e possui instalações sanitárias, receberam a melhor nota.

Os equipamentos que obtiveram valor 2,0 (conceito regular) foram os postes de iluminação alta, os bancos de madeira, as mesas de jogo e a obra de arte, devido principalmente à conservação.
Os equipamentos urbanos existentes na praça são peças importantes para o bom desempenho do local, podendo contribuir diretamente para a devida apropriação pelos usuários. O projeto do espaço deve atender às necessidades e características do público alvo, sendo que, na falta de algum equipamento, muitas vezes, a própria população costuma improvisar. Isto pode ser observado na Praça Landri Sales onde, em razão da ausência de um bicicletário, os postes de iluminação são adaptados para esta finalidade, pelas pessoas que trabalham nas proximidades ou vão ao centro para realizar alguma atividade (Figura 16). 


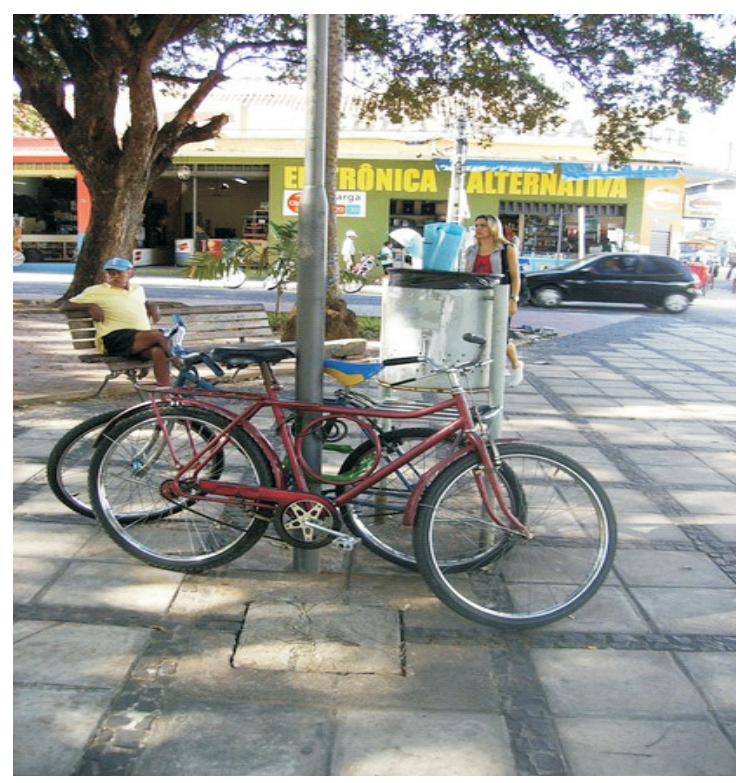

FIGURA 16 - ADAPTAÇÃO DE UM BICICLETÁRIO NA PRAÇA LANDRI SALES

FONTE: Foto Guilhermina Castro (2008).

As pessoas que apresentam algum grau de dificuldade em enxergar, ouvir ou locomover-se, encontram dificuldade em relacionar-se com o meio em que vivem, seja no lazer, trabalho, estudo, convívio social e mesmo na apropriação do espaço, por isso é importante favorecer o acesso a locais públicos com equipamentos e mobiliários adequados. A Praça possui um orelhão adaptado para pessoas especiais e rampas para facilitar o acesso, apesar de não contemplar todos os portadores de deficiências e os idosos.

$O$ busto em homenagem ao Governador Landri Sales apresenta sinais da ação de vândalos e pichadores. O pedestal é utilizando para colocar cartazes dando um aspecto de abandono.

\section{A PRAÇA E SUA RELAÇÃO COM O ENTORNO}

O entorno da Praça Landri Sales é caracterizado por pontos comerciais, predominado a venda de produtos eletrônicos, seguido de salas comerciais de con- tabilidade, advocacia e associação de classe. Existem, também, lanchonetes, bares, lan house, xerocopiadora e instituição bancária (Figura 17).

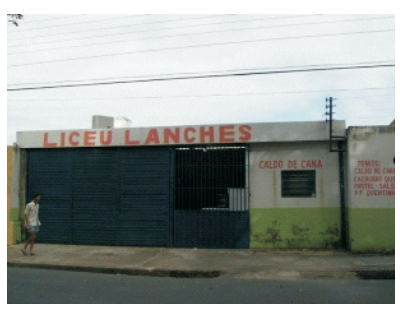

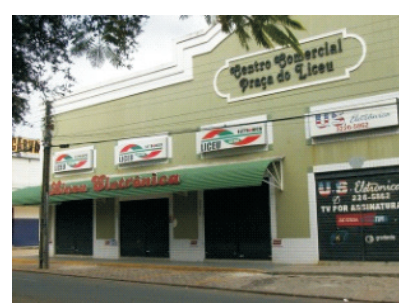

FIGURA 17 - PONTOS COMERCIAS EXISTENTES NO ENTORNO DA PRAÇA, NA RUA SIMPLÍCIO MENDES

FONTE: Foto Guilhermina Castro (2009). 
Em frente à praça há o Colégio Estadual Zacarias de Góis (Figura 18) e o SEST/SENAT - Serviço Social do Transporte e o Serviço Nacional de Aprendizagem do Transporte - SENAT (Figura 19), nas proximidades

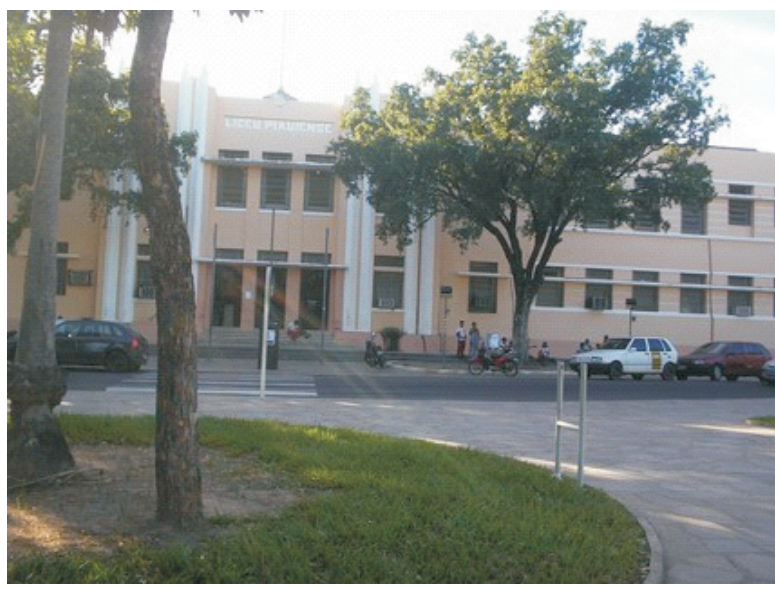

FIGURA 18 - COLÉGIO ESTADUAL ZACARIAS DE GÓIS

FONTE: Foto Guilhermina Castro.

Nas proximidades, ainda é grande a existência de residências (Figura 20), ao contrário do entorno de outras praças centrais de Teresina. A antiga casa do

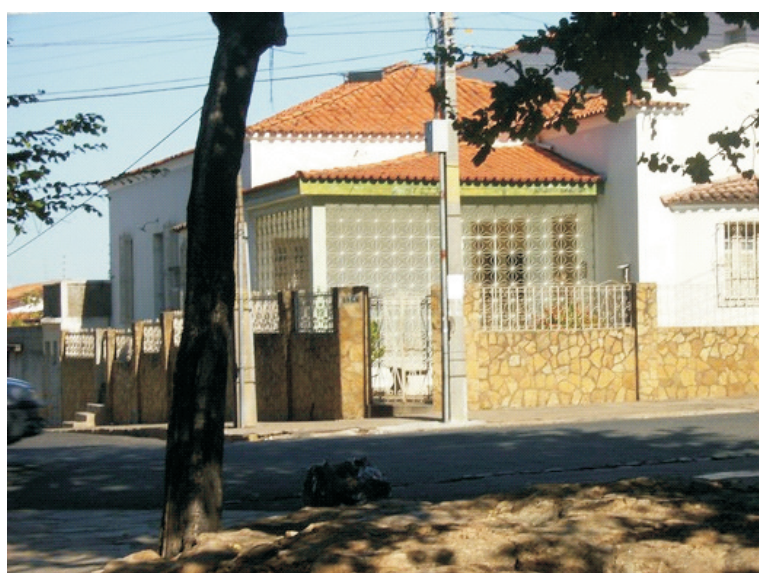

FIGURA 20 - RESIDÊNCIA EM FRETE À PRAÇA

FONTE: Foto Guilhermina Castro. estão o colégio Dante e a Unidade Escolar Clímaco D'Almeida além do SENAC (Serviço Nacional de Aprendizagem Comercial).

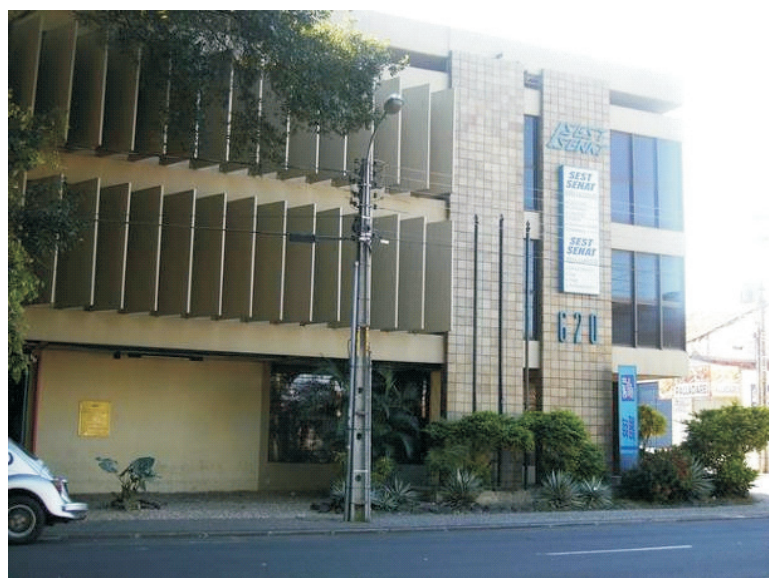

FIGURA 19 - PRÉDIO DO SEST/SENAT

FONTE: Foto Guilhermina Castro.

ex-prefeito Agenor de Almeida ainda existe, hoje, funcionando como ponto comercial (Figura 21).

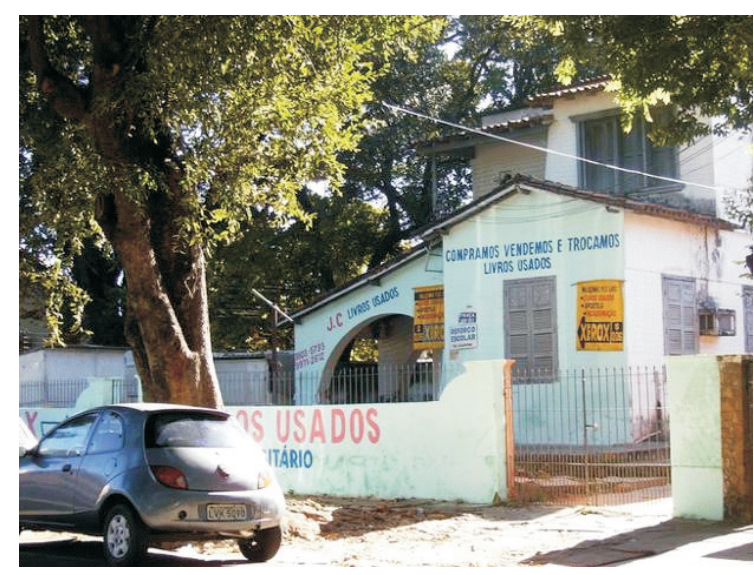

FIGURA 21 - ANTIGA RESIDÊNCIA DE AGENOR ALMEIDA FONTE: Foto Guilhermina Castro. 
Embora no entorno da Praça Landri Sales ocorra a predominância de atividades de comércio e de serviços, as edificações residenciais encontradas nas proximidades e o Colégio Estadual Zacarias de Góis fazem com que no local, ao contrário de outras praças centrais, seja bastante utilizado, favorecendo a permanência de usuários, por meio de atividades ativas e passivas.

\section{OS USUÁRIOS E AS ATIVIDADES DESENVOLVIDAS}

A percepção da imagem urbana pela população é associada a determinados espaços dentro do ambiente urbano. A percepção "é vista como um instrumento mediador entre o cidadão e o meio ambiente e a qualidade do espaço urbano" (FEIBER, 2004, p. 95).

Muitos dos frequentadores da praça são estudantes do Colégio Estadual Zacarias de Góis, conhecido como Liceu Piauiense, que fica em frente à praça, bem como os alunos do Colégio Dante e da Unidade Escolar Clímaco D'Almeida, que também ficam localizados nas proximidades. A praça é frequentada, também, pelos alunos que fazem cursos no SEST/SENAT, que fica situado na esquina com a praça.

O ponto de ônibus localizado atrás do Colégio Estadual Zacarias de Góis é outro fator que estimula a circulação de pedestre neste espaço. A presença dos estudantes é constante no espaço durante o dia todo, esperando o horário de entrada no colégio, conversando, namorando ou lanchando.

Durante a construção da praça, em 1958, foi construído um local de apoio, com área de sombra e banheiros, que segundo Cavalcanti (1958, p. 7), era "muito artística, tendo água para lavar as mãos e até água gelada para se beber, como também um espaço de fora para se estar ao fresco, com uma cobertura de muita arte". Este local funciona hoje como lanchonete, estando há 20 anos com o mesmo locatário, que denominou o espaço de "Praça de Alimentação" (Figura 22), empregando três pessoas, possuindo rendimento mensal de aproximadamente três salários.

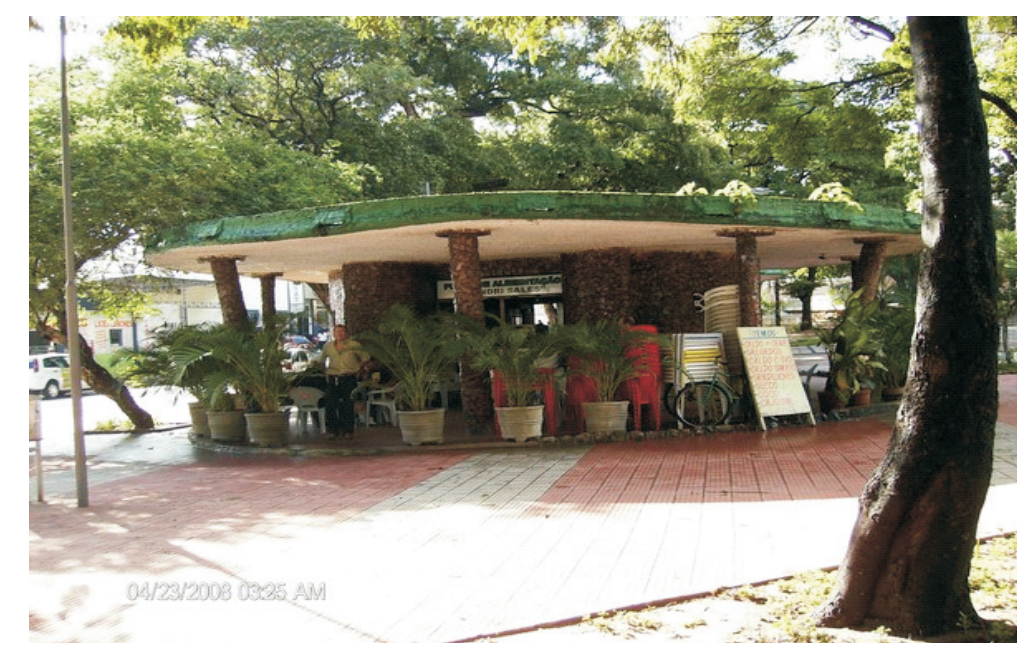

FIGURA 22 - PRAÇA DE ALIMENTAÇÃO “LANDRI SALES” NA PRAÇA LANDRI SALES

FONTE: Foto Guilhermina Castro (2008).

Esta construção possui laje de cobertura em concreto e pilares e paredes revestidas de pedra, possuindo instalações sanitárias, cozinha, proporcionando bem-estar aos seus frequentadores. O seu funcionamento é de segunda-feira a sábado abrindo às 7 h00min e fechando, geralmente, às $22 \mathrm{~h} 00 \mathrm{~min}$, oferecendo alimentação (sanduíche, caldo de carne, salgados) e bebida (refrigerante, suco, cerveja). Neste espaço os alunos costumam lanchar. Aos sábados o movimento é grande durante a tarde, quando o comércio se fecha e as pessoas vão relaxar no espaço. Trata-se de um equipamento que funciona como elemento de atração dos visitantes da praça. 
SILVA, G. C. et al. Aspectos relacionados ao uso e apropriação...

Nos horários em torno de $8 \mathrm{~h} 00 \mathrm{~min}, 11 \mathrm{~h} 30 \mathrm{~min}$ e 17h00min, que correspondem ao início do expediente comercial, horário de almoço e final de expediente aumenta o fluxo de pessoas pela praça. O entorno da praça é caracterizado praticamente por comércio e pelo ponto de ônibus existente na proximidade da praça, tornando-se caminho obrigatório para a maioria. Constatou-se, também, que durante a semana o fluxo de bicicletas é grande.

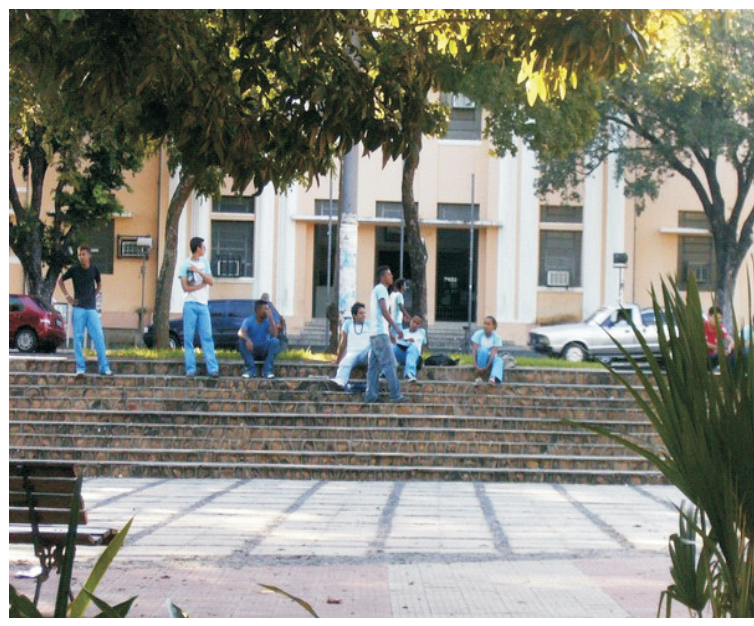

FIGURA 23 - ALUNOS SENTADOS NA ESCADARIA DA PRAÇA LANDRI SALES

FONTE: Foto Guilhermina Castro (2008).

Na praça, há dois locais onde foram inseridas mesas com bancos de concreto com a finalidade de proporcionar aos usuários a prática de jogos de tabuleiro, como, também, "apoio às atividades escolares e culturais", servindo de estímulo para a ocupação da praça (MARQUES, 2005, p. 25). Infelizmente, estes locais apresentam sinais de vandalismo. Mesmo, assim, são espaços bastante utilizados pelos estudantes e outros usuários. Para Castello (2007, p. 12), existem "certos espaços que se distinguem dentro do Espaço maior onde se situam as pessoas e, ao se distinguirem, se tornam percebidos de maneira diferente".

O espaço para jogos situado próximo á escadaria é mais utilizado das $11 \mathrm{~h} 30 \mathrm{~min}$ até as $13 \mathrm{~h} 20 \mathrm{~min}$ e no final da tarde; o outro local é mais centralizado (Figura 25), próximo ao SEST/SENAI, sendo, este mais utilizado do que as mesas de jogos perto da escadaria. O único horário que não tem pessoas neste espaço é a partir das $15 \mathrm{~h} 00 \mathrm{~min}$, quando o sol atinge diretamente este local.

Ao meio-dia, foi percebido que pessoas que trabalham nas proximidades ficam descansando na praça, esperando o horário de voltar ao trabalho, por
A escadaria da praça é muito utilizada pelos estudantes como espaço de encontro e para conversas no final da tarde (Figura 23). Acima da escadaria há quatro bancos, mas apenas dois estão, sempre, à sombra. Este espaço acaba se tornando uma extensão do colégio. Nessa área a concentração de alunos é maior nos horários de entrada e saída do colégio, por isso os alunos acabam sentando na balaustrada e na escadaria (Figura 24).

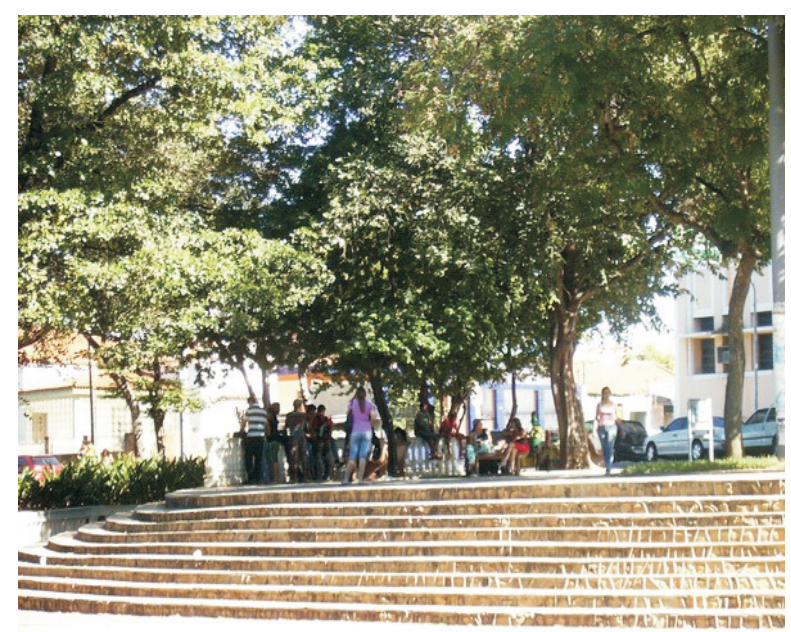

FIGURA 24 - ALUNOS OCUPANDO OS BANCOS E BALAUSTRADA DA PRAÇA LANDRI SALES

FONTE: Foto Guilhermina Castro (2008).

isso o fluxo de pessoas que vendem picolé e sorvete em carrinhos é grande.

As atividades comerciais em praças existem desde a Idade Média. Vargas (2001, p. 137 e 138) comenta que "a cidade necessita de um centro social" e que "a cultura da praça inclui o mercado" que em decorrência da concentração de pessoas apareciam "de improviso os postos provisórios, as tendas, os bancos, os errantes e os vagabundos". A Prefeitura de Teresina, depois da reforma de 2006, não permite que o comércio informal permaneça na praça, mas no sábado, que não tem fiscalização, aparecem alguns vendedores de batata-frita, água de coco, refrigerante, bombom que se instalam na praça e permanecem enquanto tem movimento, o que ajuda a atrair mais usuários ao local.

A praça se torna movimentada depois das 13h00min de sábado, quando o expediente comercial encerra e as pessoas vão para a Praça de alimentação "Praça Landri Sales". Encontra-se, também, neste espaço, ambulantes vendendo frutas, picolé, pipoca e bijuterias, que permanecem pouco tempo, dependendo da existência de clientes (Figura 26). 


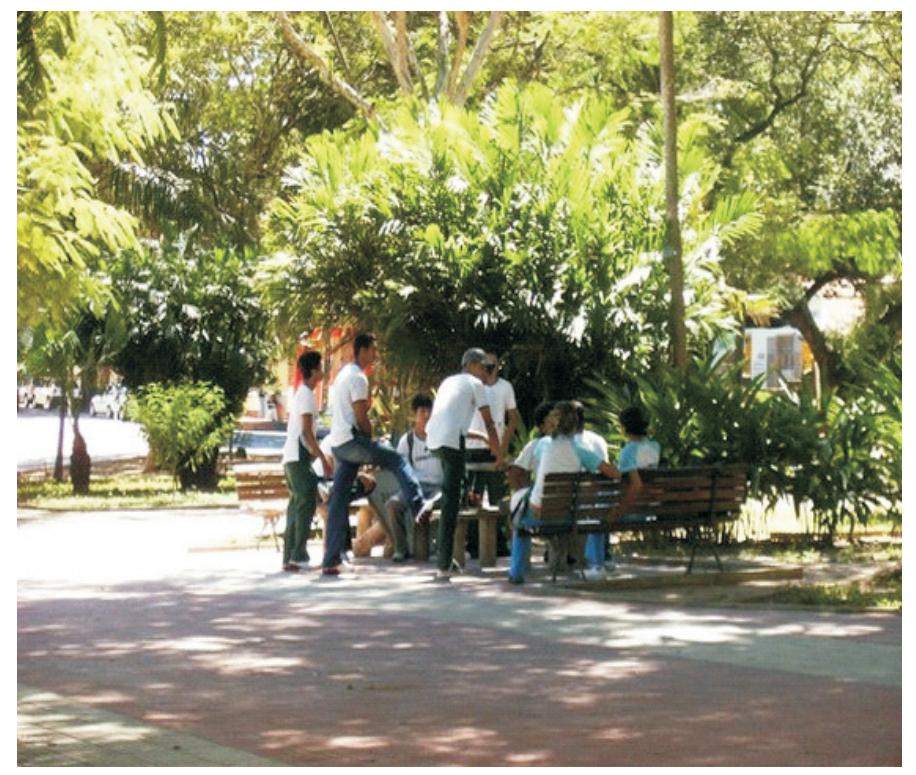

FIGURA 25 - UTILIZAÇÃO DAS MESAS DE JOGOS NA PRAÇA LANDRI SALES

FONTE: Foto Guilhermina Castro (2008).
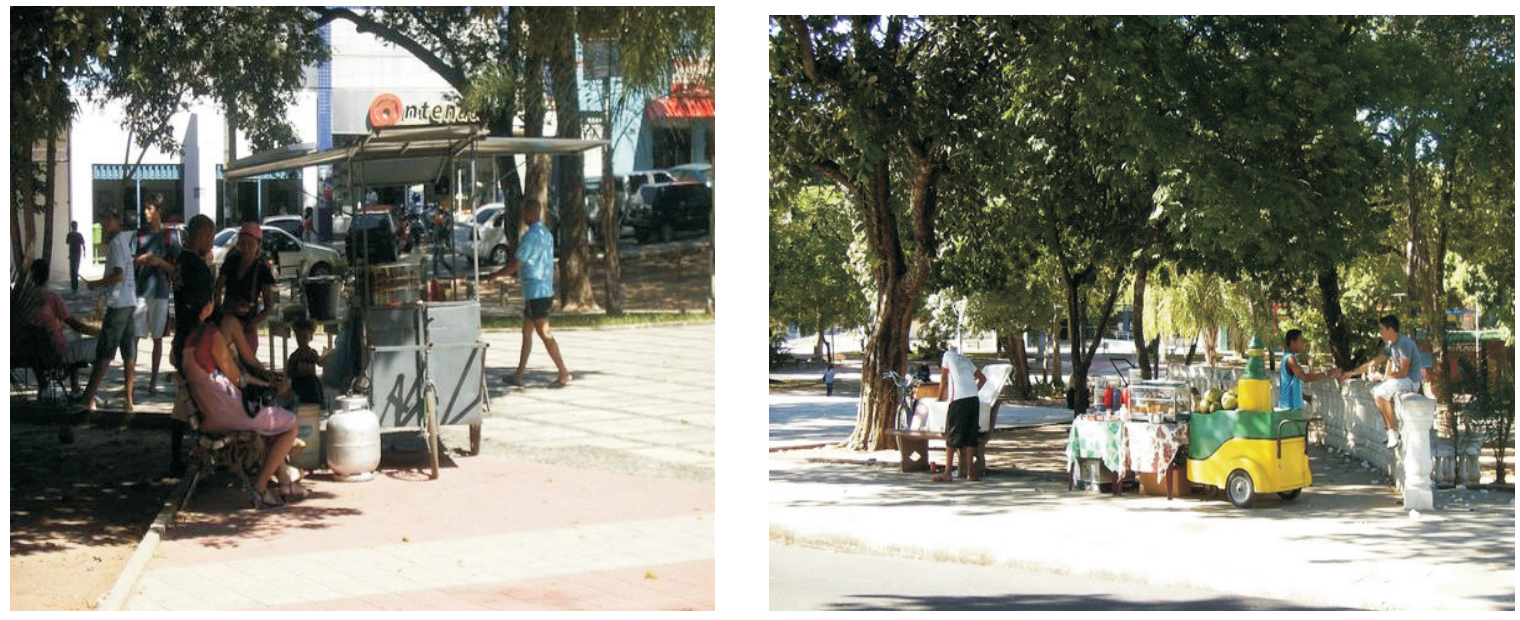

FIGURA 26 - VENDEDORES INFORMAIS NA PRAÇA LANDRI SALES

FONTE: Foto Guilhermina Castro (2008).

Há um trabalhador informal, lavador de carros, que se destaca dos demais, conhecido por Neguinho, que trabalha na praça, de domingo a domingo, há 22 anos, desde 7 de janeiro de 1987. Ele coloca sua banca na praça, onde expõe os produtos de lavagem e polimento (Figuras 27 e 28), esperando os clientes e oferecendo a comodidade de pagamento, por meio de cartões de crédito, com o apoio de um estabelecimento comercial. Utiliza o ponto de água que fica na praça, apropriando-se de um bem público, mas em troca ele zela e não deixa que danifiquem o equipamento que utiliza na sua atividade. O espaço para lavar o carro é a rua e tem um rendimento mensal de um salário e meio.

Existem outros lavadores de carros que utilizam o ponto de água na praça, eles ficam nos prédios em torno da praça e, ao contrário do Neguinho, não têm bancas e não aceitam cartões de créditos. 


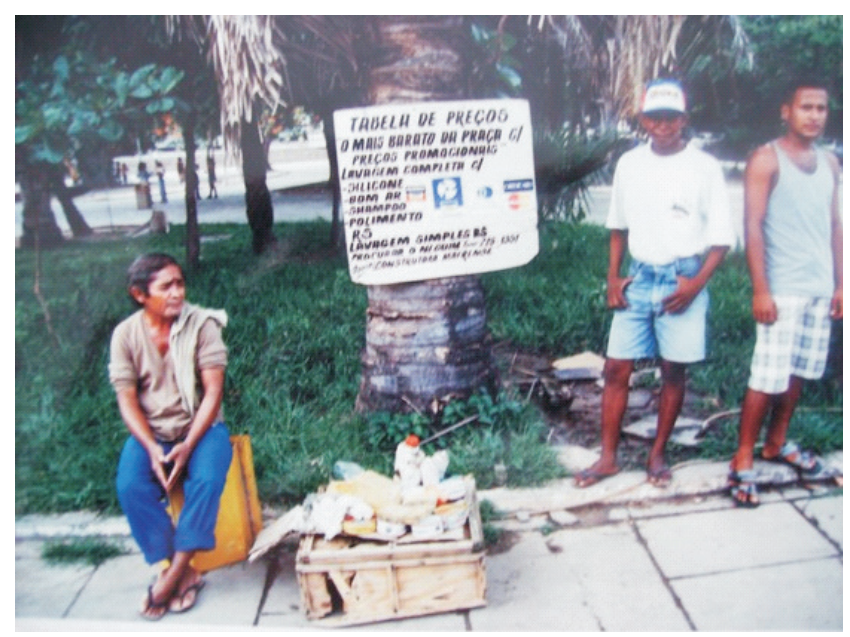

FIGURA 27 - LAVADORES DE CARRO NA PRAÇA LANDRI SALES NA DÉCADA DE 90, VENDO-SE NEGUINHO DE BONÉ

FONTE: Arquivo público.

As principais atividades exercidas pelos usuários e a caracterização do seu entorno da praça estão descritas no mapa de uso (Figura 29).

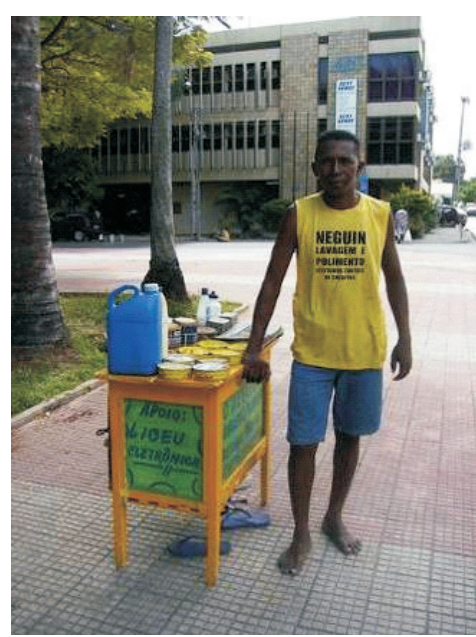

FIGURA 28 - BANCA DO NEGUINHO, LAVADOR DE CARRO NA PRAÇA LANDRI SALES, EM 2008

FONTE: Foto Guilhermina Castro (2008).

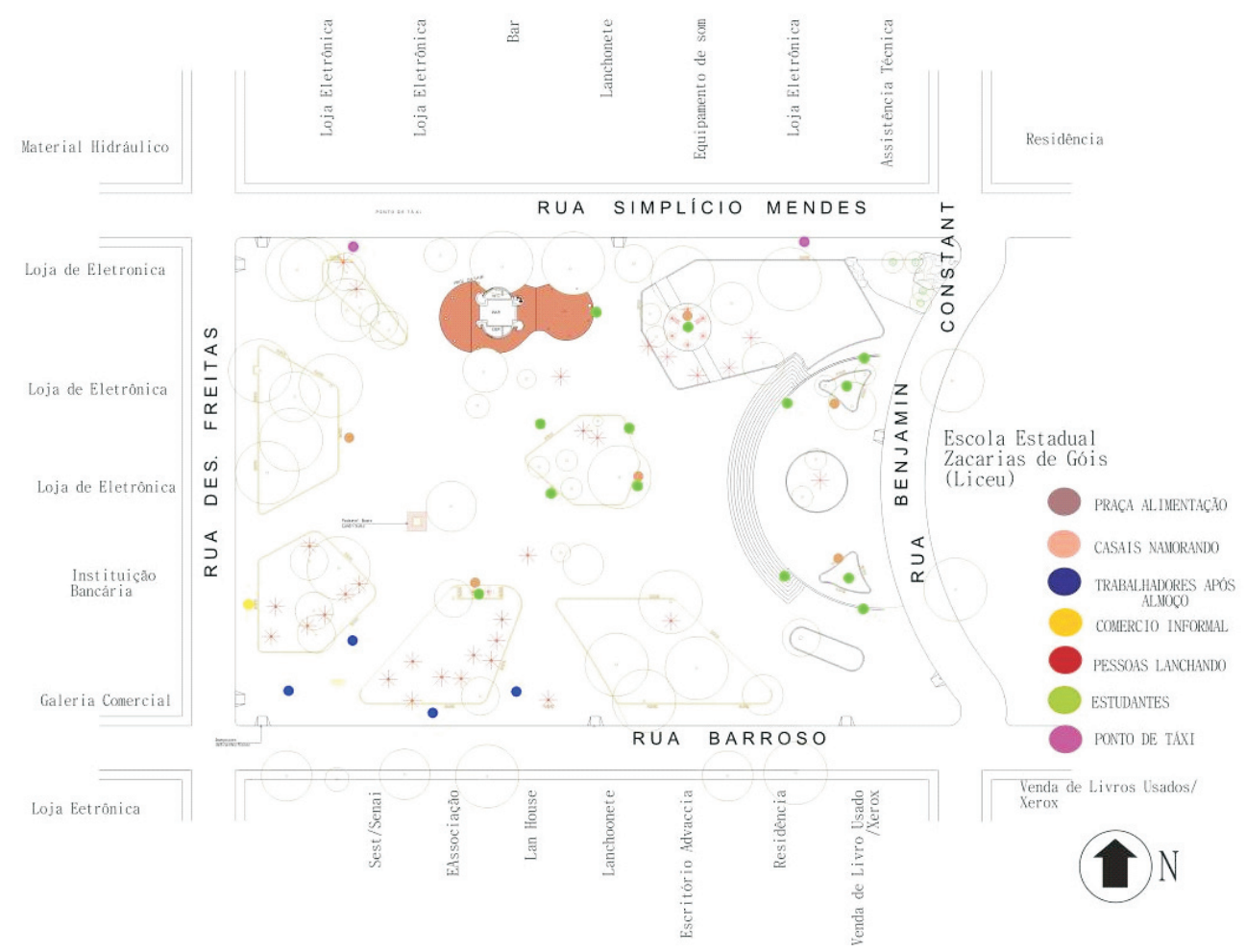

FIGURA 29 - MAPA DE USO DA PRAÇA LANDRI SALES

FONTE: SEMPLAN (2006), adaptado por Guilhermina Castro, desenhado por José H. Leal Jr. (2008). 
Como pode ser visto na figura 30 , as principais atividades exercidas na praça são passivas, tais como esperar o comércio abrir ou por alguém e, ainda, con- versar, totalizando $54 \%$. A presença dos equipamentos e mobiliários favorece estas atividades, além destas foram citadas outras atividades, como descansar e paquerar $(6,7 \%)$.

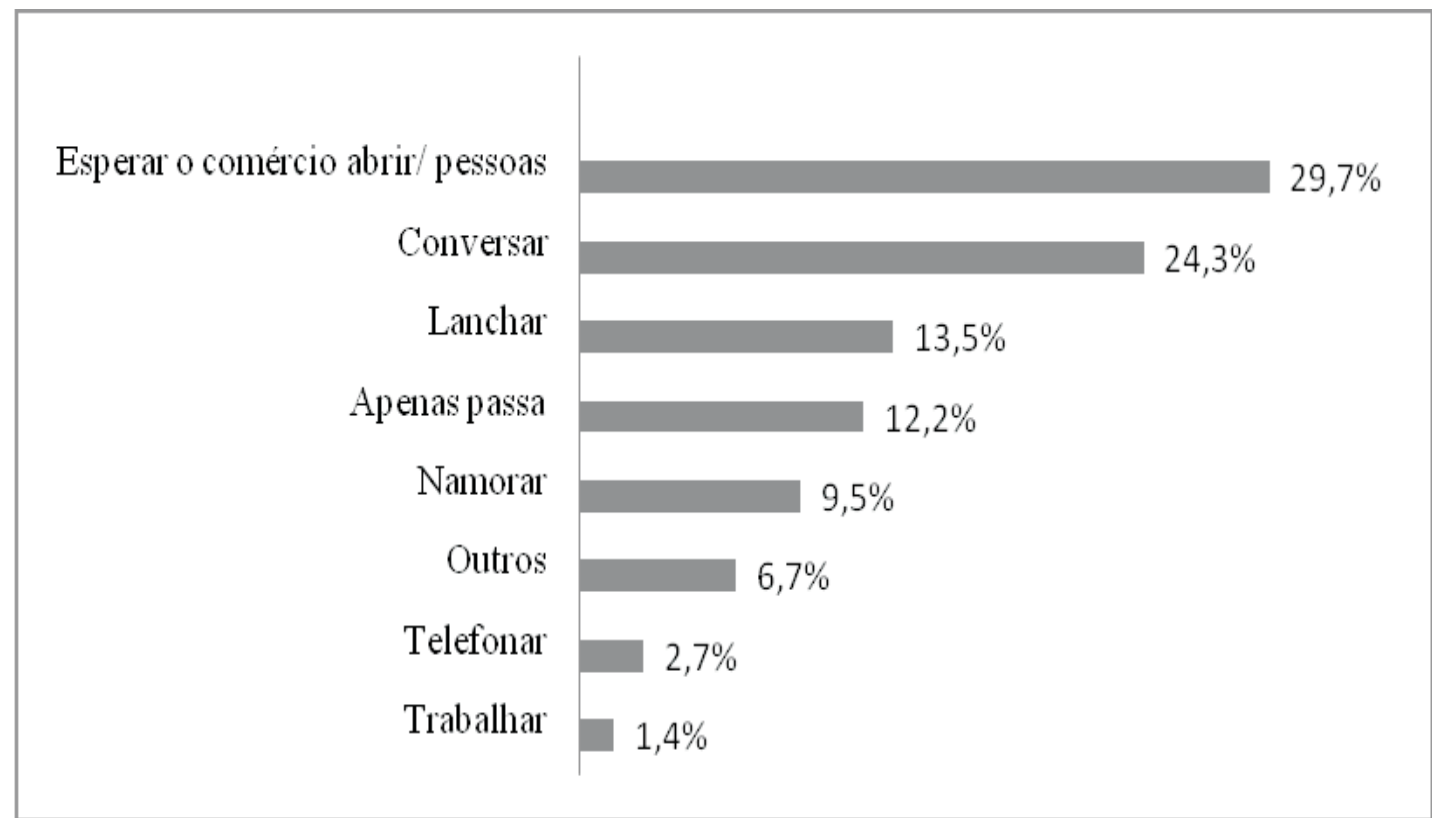

FIGURA 30 - GRÁFICO SOBRE AS ATIVIDADES NA PRAÇA LANDRI SALES

No final de semana, a praça é utilizada pelos moradores do entorno. A atividade ativa da praça se dá quando as crianças vão brincar de bola, pedalar, andar

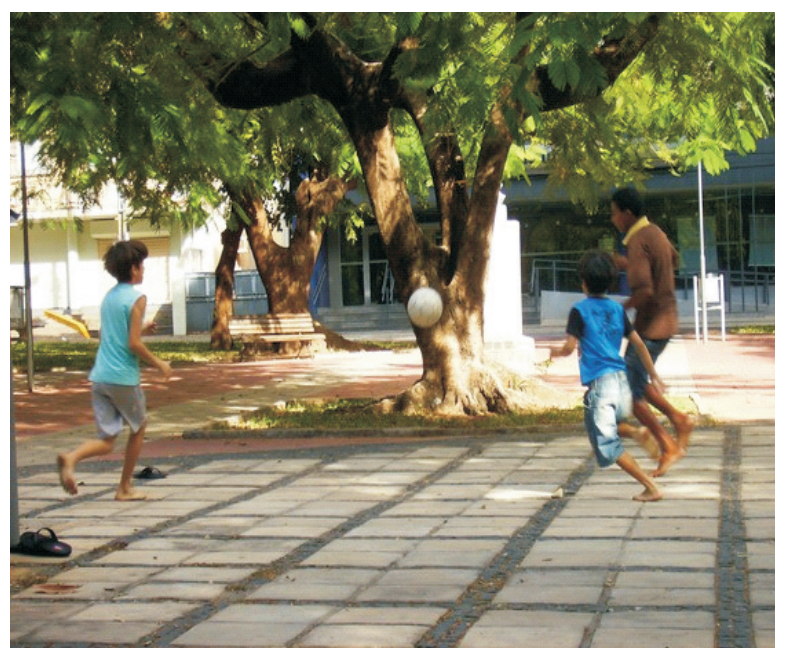

de patins e skate (Figura 31). Casais de namorados também utilizam a praça no final de semana.

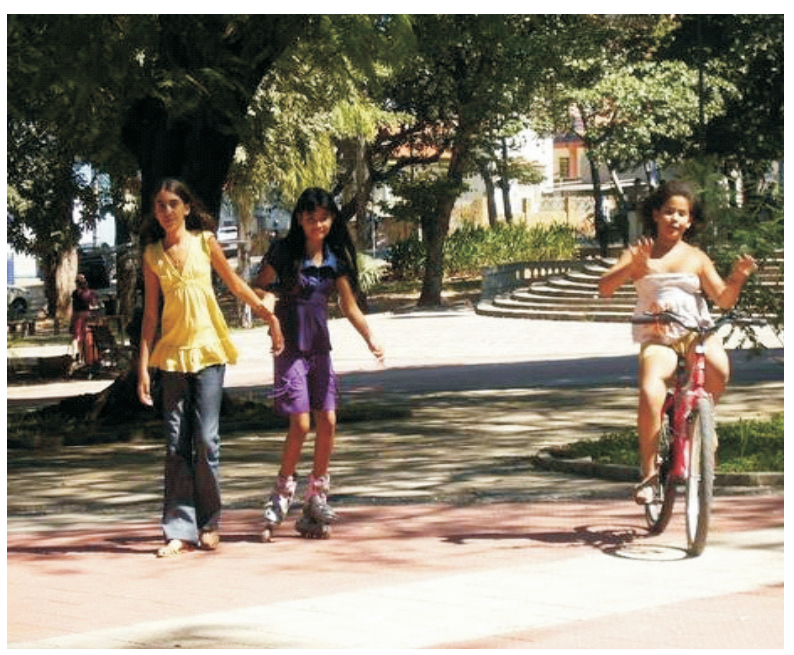

FIGURA 31 - CRIANÇAS JOGANDO, PATINANDO E PEDALANDO NA PRAÇA LANDRI SALES

FONTE: Foto Guilhermina Castro (2008). 
SILVA, G. C. et al. Aspectos relacionados ao uso e apropriação...

O que dá vida a uma praça é a sua utilização pela população através de atividades ativas e passivas. Esta praça ainda tem grande valor histórico para a cidade e valor simbólico para a população.

\section{CONSIDERAÇÕES FINAIS}

O resgate de um espaço público é importante por representar o patrimônio histórico e cultural ligado à imagem da cidade. As praças centrais acumulam importante características, configurando-se como um referencial da modificação da paisagem urbana com o passar dos anos. A Praça Landri Sales teve seu espaço delimitado desde o planejamento de Teresina, sua construção foi bem-vinda para os moradores do local como a população da cidade.

A praça, com seu estilo eclético, atraía famílias, babás com as crianças, casais de namorados e idosos por um espaço acolhedor e agradável. Com o passar dos anos, o centro da cidade passou de área residencial para comercial, trazendo modificações para a paisagem urbana. A praça também começou a sofrer modificações pelos usuários. A instalação da feira de livros usados tomou conta do espaço da praça por vários anos, danificando os equipamentos e mobiliários urbanos, afastando as pessoas que já não se identificavam com o espaço e acabaram se afastando deste espaço de lazer.

Com a reforma, em 2006, a Praça Landri Sales recuperou a sua função original onde foram restabelecidos seus equipamentos e sua cobertura vegetal. Atualmente, este espaço é utilizado como circulação de pedestres, lazer ativo, passivo, atividade comercial autorizada pela Prefeitura e no sábado, também é usada por alguns comerciantes informais. No final de semana, a praça é utilizada pelos moradores do entorno. As atividades ativas são um diferencial deste espaço, que se deve

\section{REFERÊNCIAS}

ALEX, S. Projeto da praça: convívio e exclusão no espaço público. São Paulo: Editora Senac São Paulo, 2008.

ALMEIDA, C. M. Seguindo nossos trilhos. Teresina: Gráfica Impresso, 2005. v. 1.

BARTALINI, V. Praça: a forma mais que difícil. In: Paisagens em debate. São Paulo: FAU, nov. 2005.

CASTELLO, L. A percepção de lugar: repensando o conceito de lugar em arquitetura-urbanismo. Porto Alegre: PROPARUFRGS, 2007. à presença de crianças que brincam no local. A Praça Landri Sales é espaço com movimento, um espaço vivo no centro de Teresina.

O órgão público, desde a sua reforma, não permitiu que ambulantes e camelôs permanecessem no local. As atividades informais existentes na praça são de lavadores de carros.

Apesar da reforma ter sido realizada em 2006, em dois anos a praça apresenta sinais de vandalismo com mobiliários danificados. A quantidade de bancos, postes, placas, lixeiras são razoáveis e bem distribuídos no espaço, mas a falta de manutenção do órgão público e a falta de cuidado e zelo por estes equipamentos e mobiliários por parte dos usuários é representada em bancos, lixeiras que estão quebrados e riscados. As mesas de jogos são o exemplo maior, mas apesar de estarem quebradas são espaços ainda usados, principalmente pelos estudantes. Esta situação pode ser observada em outras praças de Teresina e em outras capitais brasileiras.

É importante para os habitantes de uma cidade a preservação das áreas que fazem parte da sua memória. Além disso, é necessário se formar a consciência da importância que as praças desempenham nas cidades, tanto do ponto de vista social, servindo como ponto de encontro, de manifestações e de atividades culturais, como também pelo valor ambiental que essas áreas representam.
CASTELO BRANCO, A. E. Urbanização e Clima em Teresina. Caderno de Teresina, Teresina, ano XV, n. 35, p. 10-15, mar. 2003.

CAVALCANTI, G. S. A Praça Landri Sales. Jornal do Piauí, Teresina, p. 7, 31 ago. 1958.

COLÉGIO exige livros novos e prejudica pais de alunos. Jornal Diário do Povo, Teresina, Cidade, p. 11. 11 jan. 1997

DE ANGELIS, B. L. D.; CASTRO, R. M. de; DE ANGELIS NETO, G. Metodologia para levantamento, diagnóstico e avaliação de praças no Brasil. Engenharia civil UM., 
SILVA, G. C. et al. Aspectos relacionados ao uso e apropriação...

Guimarães - Portugal, v. 20, n. 1, p. 57-70, 2004.

DIAS, C. de C. Piauí: projetos estruturantes. Teresina: Alínea Publicações Editora, 2006.

FEIBER, S. D. Áreas verdes urbanas imagem de uso - o caso do Passeio Público de Curitiba - PR. RA'EGA, Curitiba: Editora UFPR, n. 8, p. 93-105, 2004.

GARCIA, J. R. Imagens da cidade verde. Rio de Janeiro: Litteris Editora, 2000.

GOMES, M. A. S.; SOARES, B. R. A vegetação nos centros urbanos: considerações sobre os espaços verdes em cidades médias brasileiras. Estudos Geográficos, 1. Rio Claro, p. 1929, 2003.

GRAEFF, E. A. Edifício. São Paulo: Editora Projeto, 1986 (Cadernos brasileiros de arquitetura, 7).

IBGE - Instituto Brasileiro de Geografia e Estatística. Cidades. IBGE, Brasília. 2007. Disponível em: <http://www.ibge.com.br/ cidadesat/default.php>. Acesso em: 24/7/2008.

LAMAS, J. M. R. G. Morfologia urbana e desenho da cidade. Porto: Fundação Calouste Gulbenkian/Fundação para a Ciência e a Tecnologia, 2004.

LANDIM, P. da C. Desenho da paisagem urbana: as cidades do interior paulista. São Paulo: Editora UNESP, 2004.

LOBODA, C. R.; DE ANGELIS, B. L. D. Áreas verdes públicas urbanas: conceitos, usos e funções. Ambiência, Guarapuava - PR, v. 1, n. 1, p. 125-139, jan./jun. 2005.

MACEDO, S. S. Espaços Livres. Paisagem e Ambiente: ensaios. São Paulo: FAUUSP, n. 7, p.15-56, 1995.

MARANHÃO, N. Feira do livro usado teve o movimento triplicado ontem. Jornal Diário do Povo, Teresina, 13 fev. 2005, Cidades, p. 5.

MARQUES, L. V. C. Praça Landri Sales (Praça do Liceu) Teresina - Piauí (1958-2005): aspectos históricos e paisagísticos, 2005, 27p. Trabalho de conclusão de Curso (Especialização em Paisagismo) - Instituto Camilo Filho, Teresina, 2005.
MARTINS, E. Guia de Teresina. Teresina: Gráfica IBGE, 1959.

MONTEIRO, L. R. Relatório da Câmara Municipal de Teresina. Teresina: Graphica Esperança, 1943.

MONTENEGRO, G. N. A produção do mobiliário urbano em espaços públicos: o desenho do mobiliário urbano nos Projetos de Reordenamento das Orlas do Rio Grande do Norte, 2005, 192p. Dissertação (Mestrado em Arquitetura e Urbanismo) Universidade Federal do Rio Grande do Norte, Natal, 2005.

PERIGOSA explosão. O Dia, Teresina, ano V, n. 316, p. 4, 1955.

PINHEIRO, J. de Q.; ELALI, G. A.; FERNANDES, O. S. Observando a interação pessoa-ambiente: vestígios ambientais e mapeamento comportamental. In: PINHEIRO, J. Q.; GÜNTHER, H. (Orgs.). Métodos de pesquisa nos estudos pessoa-ambiente. São Paulo: Casa do Psicólogo, 2008, p. 75-104.

PRAÇAS. Jornal do Piauí, Teresina, Cidade, p. 2. 10 nov. 1957.

SÁ CARNEIRO, A. R.; MESQUITA, L. B. Espaços livres do Recife. Recife: Prefeitura Municipal do Recife/ Universidade Federal de Pernambuco, 2000.

SEMPLAN - Secretaria Municipal de Planejamento. Mapa digital da Praça Landri Sales, 2006.

SIRKIS, A. O desafio ecológico das cidades. In: TRIGUEIRO, A. (Coord.). Meio ambiente no século 21: especialistas falam da questão ambiental nas suas áreas de conhecimento. Rio de Janeiro: Sextante, 2003, p. 215-229.

SPIRN, A. W. O jardim de granito: a natureza no desenho da cidade. Tradução de: Paulo Pellegrino. São Paulo: Ed. Universidade de São Paulo, 1995.

VARGAS, H. C. Espaço terciário: o lugar, a arquitetura e a imagem do comércio. São Paulo: Editora SENAC São Paulo, 2001. 